\title{
How did Marine Isotope Stage 3 and Last Glacial Maximum climates differ? - Perspectives from equilibrium simulations
}

\author{
C. J. Van Meerbeeck ${ }^{1}$, H. Renssen ${ }^{1}$, and D. M. Roche ${ }^{1,2}$ \\ ${ }^{1}$ Department of Earth Sciences - Section Climate Change and Landscape Dynamics, Faculty of Earth and Life Sciences, VU \\ University Amsterdam, de Boelelaan 1085, 1081HV Amsterdam, The Netherlands \\ ${ }^{2}$ Laboratoire des Sciences du Climat et de l'Environnement (LSCE/IPSL), Laboratoire CEA/INSU-CNRS/UVSQ, C.E. de \\ Saclay, Orme des Merisiers Bat. 701, 91190 Gif sur Yvette Cedex, France
}

Received: 15 August 2008 - Published in Clim. Past Discuss.: 6 October 2008

Revised: 14 January 2009 - Accepted: 20 February 2009 - Published: 5 March 2009

\begin{abstract}
Dansgaard-Oeschger events occurred frequently during Marine Isotope Stage 3 (MIS3), as opposed to the following MIS2 period, which included the Last Glacial Maximum (LGM). Transient climate model simulations suggest that these abrupt warming events in Greenland and the North Atlantic region are associated with a resumption of the Thermohaline Circulation (THC) from a weak state during stadials to a relatively strong state during interstadials. However, those models were run with LGM, rather than MIS3 boundary conditions. To quantify the influence of different boundary conditions on the climates of MIS3 and LGM, we perform two equilibrium climate simulations with the threedimensional earth system model LOVECLIM, one for stadial, the other for interstadial conditions. We compare them to the LGM state simulated with the same model. Both climate states are globally $2^{\circ} \mathrm{C}$ warmer than LGM. A striking feature of our MIS3 simulations is the enhanced Northern Hemisphere seasonality, July surface air temperatures being $4^{\circ} \mathrm{C}$ warmer than in LGM. Also, despite some modification in the location of North Atlantic deep water formation, deep water export to the South Atlantic remains unaffected. To study specifically the effect of orbital forcing, we perform two additional sensitivity experiments spun up from our stadial simulation. The insolation difference between MIS3 and LGM causes half of the $30-60^{\circ} \mathrm{N}$ July temperature anomaly $\left(+6^{\circ} \mathrm{C}\right)$. In a third simulation additional freshwater forcing halts the Atlantic THC, yielding a much colder North Atlantic region $\left(-7^{\circ} \mathrm{C}\right)$. Comparing our simulation with proxy data, we find that the MIS3 climate with collapsed THC
\end{abstract}

\section{Correspondence to: \\ C. J. Van Meerbeeck \\ (cedric.van.meerbeeck@falw.vu.nl)}

mimics stadials over the North Atlantic better than both control experiments, which might crudely estimate interstadial climate. These results suggest that freshwater forcing is necessary to return climate from warm interstadials to cold stadials during MIS3. This changes our perspective, making the stadial climate a perturbed climate state rather than a typical, near-equilibrium MIS3 climate.

\section{Introduction}

Marine Isotope Stage 3 (MIS 3) - a period between 60 and $27 \mathrm{ka}$ ago during the last glacial cycle - experienced several abrupt climatic warming phases known as DansgaardOeschger (DO) events. Registered in Greenland ice core oxygen isotope records (see Fig. 1), DO events are abrupt transitions from cold, stadial climate conditions to mild, interstadial conditions, eventually followed by a return to cold stadial conditions (Dansgaard et al., 1993). Temperature reconstructions of DO shifts in Greenland suggest a rapid mean annual surface air temperature rise of up to $15^{\circ} \mathrm{C}$ in a few decades (Severinghaus et al., 1998; Huber et al., 2006). In addition, within certain stadials, massive ice surges from the Laurentide Ice Sheet flushed into the North Atlantic Ocean during so-called Heinrich events (Heinrich, 1988). These DO events and Heinrich events (HEs) are correlated with rapid climatic change in the circum-North Atlantic region (Bond et al., 1993; van Kreveld et al., 2000; Hemming, 2004; Rasmussen and Thomsen, 2004). It is presently not clear, however, why DO events were so frequent during MIS 3, while being nearly absent around the Last Glacial Maximum (LGM). Here, the LGM is considered to be the period between roughly 21 and $19 \mathrm{ka}$ ago with largest ice sheets of the

Published by Copernicus Publications on behalf of the European Geosciences Union. 
Insolation changes and NorthGRIP d180 curve for $70 \mathrm{ka} \mathrm{BP}$ to present

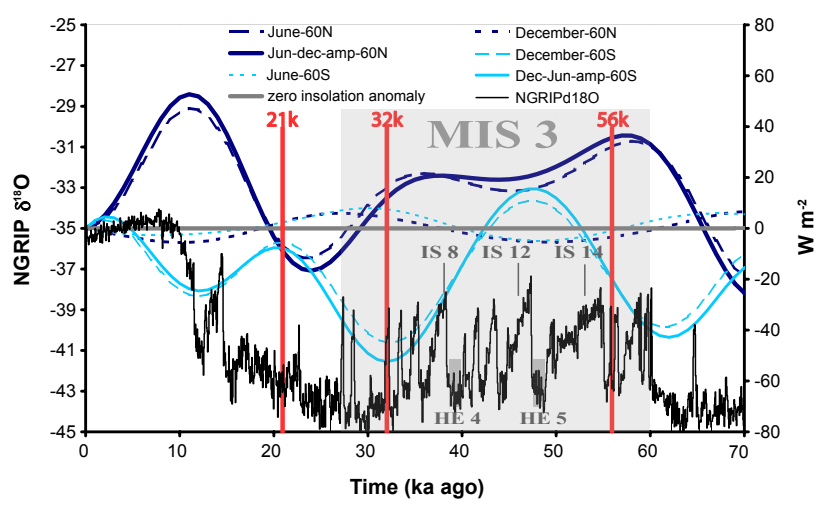

Fig. 1. The NorthGRIP ${ }^{18} \mathrm{O}$ curve (black - NorthGRIP Members, 2004) from 0 to $70 \mathrm{ka}$ ago on the ss09sea time scale. MIS 3 is shaded in grey. Greenland interstadials DO 8, DO 12 and DO 14, and Heinrich events HE 4 and HE 5 are shown. Superimposed are the summer (dashed lines) and winter (dotted lines) insolation anomalies compared to present-day at $60^{\circ} \mathrm{N}$ (dark blue) and $60^{\circ} \mathrm{S}$ (light blue), which results from orbital changes. Our modelling experiments are setup with the orbital parameter values at 56, 32 and $21 \mathrm{ka} \mathrm{BP}$, as marked in red. (Insolation is defined as the top-of-theatmosphere incoming solar radiation).

last glacial. Therefore, we analyse in this paper some characteristic features of the MIS3 climate and compare them to the LGM climate, using climate modelling results.

Several attempts have been made to uncover the mechanisms that underlie millennial-scale glacial climatic changes. It has been hypothesised (e.g., Broecker et al., 1990) that DO events result from changes in strength of the Atlantic Thermohaline Circulation (THC). The onset of a DO event could represent a sudden resumption from a reduced or collapsed THC state during a stadial to a relatively strong interstadial state (Broecker et al., 1985). This would instantaneously increase the northward oceanic heat transport in the Atlantic. The additional heat is then released to the atmosphere in the mid- and high latitudes over and around the North Atlantic, mostly in winter time. The strength of Atlantic THC depends on the density of surface water masses in the high latitudes, where deep water can be formed through convection when the water column is poorly stratified. Stratification occurs when freshwater flows to convection sites in the high latitudes of the North Atlantic Ocean or the Nordic Seas. This could for instance have occurred during HEs, when the freshwater released by huge amounts of melting icebergs is thought to have caused a THC shutdown (e.g., Broecker, 1994; Stocker and Broecker, 1994).

It is currently uncertain what drives changes in ice sheet mass balance associated with HEs and DO events (Clark et al., 2007). A negative mass balance can be achieved by reduced snow accumulation, ice calving or by enhanced melting, or a combination of these processes. Either internal os- cillations in the dynamics of the climate system, or variations in an external energy source can increase ablation. In the first case, a periodical decay of the ice volume takes place. According to MacAyeal (1993)'s binge/purge model, approximately every 7000 years, ice berg armada's from the Laurentide Ice Sheet (HEs) occurred after basal melt lubricated the bedrock of the Hudson Bay and Hudson Strait, which created an ice stream (purge phase). Basal melt occurred after several thousands of years of slow ice accumulation, as basal ice temperature increased to attain melting point due to growing geothermal heat excess and pressure from the overlying ice (binge or growth phase). In the second case, energy input into the climate system oscillates at a frequency aligned with DO event recurrence, or at a lower or higher frequency - if the frequency of the events is modulated by the forcing (Ganopolski and Rahmstorf, 2002; Rial and Yang, 2007). An example of external forcing with lower frequency than DO recurrence is insolation changes by orbital forcing (Berger, 1978; Berger and Loutre, 1991; Lee and Poulsen, 2008). In the mid and high latitudes of the Northern Hemisphere the amount of insolation is mostly controlled by the obliquity and precession signals. July insolation at $65^{\circ} \mathrm{N}$ has been higher during MIS 3 than at LGM, with an average $446 \mathrm{~W} \mathrm{~m}^{-2}$ over the $60-30 \mathrm{ka} \mathrm{BP}$ interval compared to $418 \mathrm{~W} \mathrm{~m}^{-2}$ at $21 \mathrm{ka} \mathrm{BP}$, see Fig. 1. This provided a positive summer forcing to the climate system, so more energy may have been available for ice melting, which may have resulted in the smaller ice sheets observed during MIS 3 than during MIS 4 and MIS 2 (e.g. Svendsen et al., 2004; Helmens et al., 2007).

In an effort to better understand the processes that drove MIS 3 climate over Europe, the Stage 3 project (van Andel, 2002) involved several modelling exercises designed at reproducing as closely as possible the reconstructions from proxy climate archives (Barron and Pollard, 2002; Pollard and Barron, 2003; Alfano et al., 2003; van Huissteden et al., 2003). Barron and Pollard (2002) and Pollard and Barron (2003) concluded that MIS 3 variations in orbital forcing, Scandinavian Ice Sheet size, and $\mathrm{CO}_{2}$ concentrations could not explain the differences between a cold state and a milder state registered in the records. They attributed part of the range of air temperature differences between the milder and the cold state to colder North Atlantic and Nordic Seas sea surface temperatures and the associated extended southward distribution of sea ice in the stadial state. The remaining temperature differences might be attributed to physical processes that are unsolved by their model, e.g. oceanic circulation changes. The main limitation of Barron and Pollard (2002) and Pollard and Barron (2003) is the use of a GCM without an interactive oceanic model. This means that they forced their atmospheric model with estimated MIS 3 SSTs for a cold state and a milder state. Their experiments were thus not designed to explain the mechanisms behind the oceanic circulation changes seen in data between stadials and interstadials (e.g. Dokken and Jansen, 1999). 
Compared to the work of Barron and Pollard (2002) and Pollard and Barron (2003), we investigate several additional, potential drivers of MIS 3 climate change. We estimate the climate sensitivity to $\mathrm{CO}_{2}, \mathrm{CH}_{4}$ and $\mathrm{N}_{2} \mathrm{O}$ as well as atmospheric dust concentration changes between stadial and interstadial values when the oceanic circulation and the atmospheric circulation are coupled. In addition, we investigate how, compared to LGM, stronger Northern Hemisphere summer insolation and smaller ice sheet size affected the MIS 3 climate. To do so, we simulate two quasi-equilibrium states with the LOVECLIM earth system model (Driesschaert, 2005). These states are obtained by imposing typical, but constant MIS 3 boundary conditions as well as stadial (MIS3-sta) and interstadial (MIS3-int) greenhouse gas and dust forcings, respectively.

To quantify the Northern Hemisphere summer warming caused by insolation changes, we perform two additional experiments, with all forcings and boundary conditions equal to MIS3-sta, except for the orbital parameters, which we set at $21 \mathrm{ka}$ and $32 \mathrm{ka} \mathrm{BP}$, respectively. We also studied the sensitivity of the THC strength to freshwater forcing in the "stadial' state (MIS3-HE), as numerous such studies have shown that THC-shifts could indeed be responsible for millennialscale climate variability during the last glacial (e.g., Rahmstorf, 1996; Sakai and Peltier, 1997; Ganopolski and Rahmstorf, 2001; Schulz, 2002; Wang and Mysak, 2006; Weber et al., 2007). It is not clear to what extent these previous results are applicable to the MIS3 climate, as their authors have used LGM as an analogue of stadials. Concomitantly, with our sensitivity experiments, we compare our findings to those of Barron and Pollard (2002) and Pollard and Barron (2003) regarding the surface air temperature impact of orbital changes during MIS 3 and reduced SSTs from a warm to a cold state. Finally, we elaborate on how to better design modelling experiments that study DO-like behaviour of the climate system.

\section{Methods}

\subsection{Model}

We performed our simulations with the three-dimensional coupled earth system model of intermediate complexity LOVECLIM (Driesschaert, 2005). Its name refers to five dynamic components included (LOCH-VECODE-ECBiltCLIO-AGISM). In this study, only three coupled components are used, namely ECBilt - the atmospheric component, CLIO - the ocean component, and VECODE - the vegetation module.

The atmospheric model ECBilt is a quasi-geostrophic, T21 horizontal resolution spectral model - corresponding to $\sim 5.6^{\circ}$ latitude $\times \sim 5.6^{\circ}$ longitude - with three vertical levels (Opsteegh et al., 1998). Its parameterisation scheme allows for fast computing and includes a linear longwave radiation scheme. ECBilt contains a full hydrological cycle, including a simple bucket model for soil moisture over continents, and computes synoptic variability associated with weather patterns. Precipitation falls in the form of snow with temperatures below $0^{\circ} \mathrm{C}$. CLIO is a primitiveequation three-dimensional, free-surface ocean general circulation model coupled to a thermodynamical and dynamical sea-ice model (Goosse and Fichefet, 1999). CLIO has a realistic bathymetry, a $3^{\circ}$ latitude $\times 3^{\circ}$ longitude horizontal resolution and 20 levels in the vertical. The free-surface of the ocean allows introduction of a real freshwater flux (Tartinville et al., 2001). In order to bring precipitation amounts in ECBilt-CLIO closer to observations, a negative precipitation flux correction is applied over the Atlantic and Arctic Oceans to correct for excess precipitation. This flux is reintroduced in the North Pacific. The climate sensitivity of ECBilt to a doubling in atmospheric $\mathrm{CO}_{2}$ concentration is $1.8^{\circ} \mathrm{C}$, associated with a global radiative forcing of $3.8 \mathrm{~W} \mathrm{~m}^{-2}$ (Driesschaert, 2005). The dynamic terrestrial vegetation model VECODE computes herbaceous plant and tree plus desert fractions in each land grid cell (Brovkin et al., 1997) and is coupled to ECBilt through the surface albedo.

LOVECLIM produces a generally realistic modern climate (Driesschaert, 2005) and an LGM climate generally consistent with data (Roche et al., 2007).

\subsection{Experimental design}

In order to simulate realistic features of the MIS 3 climate, the model was first setup with LGM boundary conditions and forcings, then spun-up to quasi-equilibrium state (Roche et al., 2007). These forcings (Table 1) include LGM atmospheric $\mathrm{CO}_{2}, \mathrm{CH}_{4}$ and $\mathrm{N}_{2} \mathrm{O}$ concentrations, LGM atmospheric dust content (after Claquin et al., 2003) and $21 \mathrm{ka} \mathrm{BP}$ insolation (Berger and Loutre, 1992). Other boundary conditions were modified. Bathymetry and land-sea mask were adapted to a sea level $120 \mathrm{~m}$ below present-day (Lambeck and Chappell, 2001), and the ice sheet extent and volume was taken from Peltier (2004)'s ICE-5G 21k, interpolated on the ECBilt grid.

To obtain the MIS3-sta and MIS3-int simulations, the model was subsequently set-up for MIS3 conditions. The difference in the experimental setup between MIS3-sta and MIS3-int was only due to greenhouse gas and dust forcing, since the insolation and icesheets were kept identical. In both experiments, insolation was set to its $56 \mathrm{ka} \mathrm{BP}$ values (Berger and Loutre, 1991). Ice sheet extent and topography for MIS 3 were worked out as a best guess - with consideration of controversial evidence on their configuration. They were modified after the ICE-5G modelled ice sheet topography (Peltier, 2004) averaged over 60 to $30 \mathrm{ka}$ BP (using interpretations from Svendsen et al., 2004; Ehlers and Gibbard, 2004) and interpolated at ECBilt grid-scale (see Fig. 2). We used the LGM land-sea mask in all our MIS 3 simulations. Considering the small area that would be influenced by 
Table 1. Boundary conditions for our experiments compared to the LGM experiment.

\begin{tabular}{lllllllll}
\hline & $\begin{array}{l}\mathrm{CO}_{2} \\
(\mathrm{ppmv})\end{array}$ & $\begin{array}{l}\mathrm{CH}_{4} \\
(\mathrm{ppbv})\end{array}$ & $\begin{array}{l}\mathrm{N}_{2} \mathrm{O} \\
(\mathrm{ppbv})\end{array}$ & dust factor & $\begin{array}{l}\text { orbital forcing } \\
(\mathrm{ka} \mathrm{BP})\end{array}$ & $\begin{array}{l}\text { fresh water } \\
(\mathrm{Sv})\end{array}$ & $\begin{array}{l}\text { ice sheets } \\
(\mathrm{ka} \mathrm{BP})\end{array}$ & $\begin{array}{l}\text { land-sea mask } \\
(\mathrm{ka} \mathrm{BP})\end{array}$ \\
\hline LGM & 185 & 350 & 200 & 1 & 21 & 0 & 21 & 21 \\
MIS3-sta & 200 & 450 & 220 & 0.8 & 56 & 0 & MIS 3 & 21 \\
MIS3-int & 215 & 550 & 260 & 0.2 & 56 & 0 & MIS 3 & 21 \\
MIS3-sta-32k & 200 & 450 & 220 & 0.8 & 32 & 0 & MIS 3 & 21 \\
MIS3-sta-21k & 200 & 450 & 220 & 0.8 & 21 & 0 & MIS 3 & 21 \\
MIS3-HE & 200 & 450 & 220 & 0.8 & 56 & 0.3 & MIS 3 & 21 \\
\hline
\end{tabular}

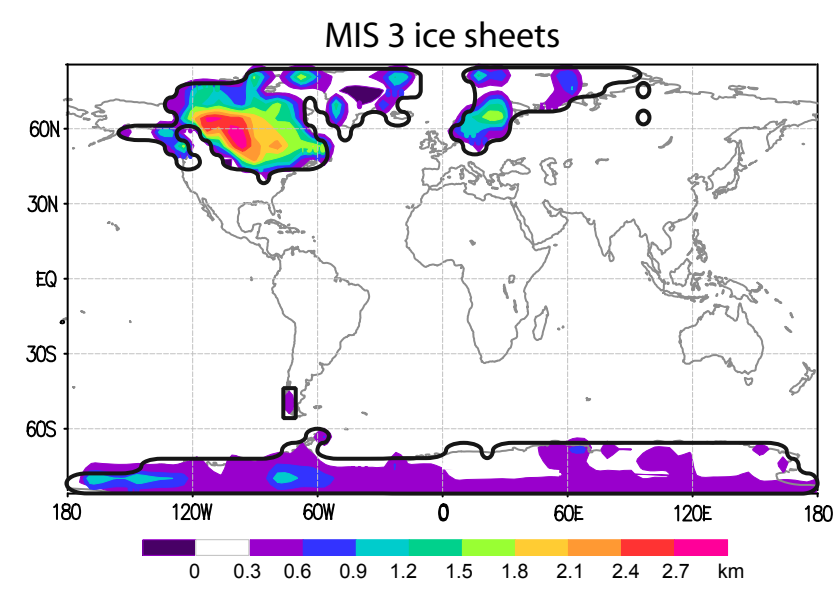

Fig. 2. Best estimate average MIS 3 ice sheet extent (thick black line) and additional topography compared to present-day ones (colour scale).

a relative higher sea-level compared to LGM, we assume that the impact of using an LGM land-sea mask in our MIS 3 experiments is minor. Moreover, sea level reconstructions are scarce and poorly resolved for MIS 3, with estimated sea levels of approximately between 60 and $90 \mathrm{~m}$ below present-day sea level (Chappell, 2002). However, in our model, maintaining the LGM land-sea mask implies that the Barents and Kara Seas were for the most part land mass. Therefore we set the albedo of these grid cells to a constant value of 0.8 , which is the same as for ice sheets. On a local scale, we only expect a small energy balance bias in using continental ice as the heat flux between ocean, sea-ice and the atmosphere are discarded for these cells.

MIS3-sta (MIS3-int) was additionally forced with average MIS 3 stadial (interstadial) atmospheric GHG concentrations and top of the atmosphere albedo taking into account the effect of elevated atmospheric dust concentrations (see Table 1). The GHG concentrations we used in the setup of MIS3-sta and MIS3-int are based on typical concentrations found in the ice core records for stadials, respectively interstadials 8 and 14 (Indermühle, 2000; Flückiger et al., 2004).
We made a stack of all records during these intervals and selected the (rounded) mean value of the spline functions in the stadials, respectively interstadials as final GHG concentrations. The very much simplified dust forcing was calculated by multiplying the grid cell values of the LGM forcing map of Claquin et al. (2003), adapted in Roche et al. (2007) with an empirical dust factor corresponding to a best-guess of the average atmospheric dust-content (following the NGRIP $\delta^{18} \mathrm{O}$ record - NorthGRIP Members, 2004) during an MIS 3 stadial or interstadial. The factor is inferred from an exponential transfer function of the NorthGRIP $\delta^{18} \mathrm{O}$ record (we derived Eqs. 1-3), which explains most of the anticorrelation between the NorthGRIP dust and $\delta^{18} \mathrm{O}$ records. The dust factors are based on findings of Mahowald et al. (1999) and Mahowald et al. (2006) that, on average, globally the atmospheric dust content was about five times lower during interstadials compared to full glacial conditions. In the Greenland ice core records, dust concentration peaks during stadials did at times attain LGM values. Applying this to our parameterisation, would give a dust factor of 1 in such cases. However, averaged over the duration of a stadial, the dust content seems slightly lower than $21 \mathrm{ka}$ ago. Therefore, we opted for a stadial average of 0.8 . The transfer function is:

for $\delta^{18} O \leq-43$ per mil $\rightarrow$ dust factor $=1$

for $\delta^{18} O \geq-39$ per mil $\rightarrow$ dust factor $=0$

else dust factor $=5^{\frac{-\delta^{18} O-43}{4}}$

Starting from the LGM state, we ran the model twice - with the respective MIS3-sta and MIS3-int forcings - for 7500 years to obtain two states in quasi-equilibrium with MIS 3 "stadial" and "interstadial" conditions respectively. We compare the last 100 years of the results of our simulation with the LGM climate simulations of Roche et al. (2007). For certain variables, output on daily basis is analysed over an additional 50-year interval in order to carefully assess seasonality in Europe. 
Table 2. Comparison of MIS3 and LGM surface air temperatures (in ${ }^{\circ} \mathrm{C}$, values between brackets are $1 \sigma$ ).

\begin{tabular}{lllll}
\hline Area & Global & Europe & North Atlantic & South Ocean \\
\hline${ }^{\circ} \mathrm{E}$ & -180 to 180 & -12 to 50 & -60 to -12 & -180 to 180 \\
${ }^{\circ} \mathrm{N}$ & -90 to 90 & 30 to 72 & 30 to 72 & -65 to -50 \\
Year & & & & \\
LGM & $11.5(0.1)$ & $4.1(0.5)$ & $5.1(0.4)$ & $-4.4(0.2)$ \\
MIS3-sta & $13.2(0.1)$ & $8.8(0.5)$ & $8.1(0.5)$ & $-1.6(0.2)$ \\
MIS3-sta vs LGM & $\mathbf{1 . 7}$ & $\mathbf{4 . 7}$ & $\mathbf{3 . 0}$ & $\mathbf{2 . 8}$ \\
MIS3-int & $13.5(0.1)$ & $9.5(0.5)$ & $9.0(0.3)$ & $-0.5(0.2)$ \\
MIS3-int vs sta & $\mathbf{0 . 3}$ & $\mathbf{0 . 7}$ & $\mathbf{0 . 9}$ & $\mathbf{1 . 1}$ \\
MIS3-HE & $12.0(0.1)$ & $1.4(0.6)$ & $1.4(0.5)$ & $-1.2(0.3)$ \\
MIS3-HE vs sta & $-\mathbf{1 . 2}$ & $-\mathbf{7 . 4}$ & $-\mathbf{6 . 9}$ & $\mathbf{0 . 4}$ \\
January & & & & \\
LGM & $10.0(0.3)$ & $-4.9(1.7)$ & $1.4(1.1)$ & $1.6(0.2)$ \\
MIS3-sta & $11.0(0.2)$ & $-1.7(1.3)$ & $4.4(0.7)$ & $3.7(0.2)$ \\
MIS3-sta vs LGM & $\mathbf{1 . 0}$ & $\mathbf{3 . 2}$ & $\mathbf{3 . 5}$ & $\mathbf{1 . 9}$ \\
MIS3-int & $11.3(0.2)$ & $-0.9(1.0)$ & $5.5(0.4)$ & $4.0(0.2)$ \\
MIS3-int vs sta & $\mathbf{0 . 4}$ & $\mathbf{0 . 7}$ & $\mathbf{0 . 4}$ & $\mathbf{0 . 6}$ \\
MIS3-HE & $9.7(0.2)$ & $-9.4(1.5)$ & $-4.4(1.5)$ & $3.9(0.2)$ \\
MIS3-HE vs sta & $-\mathbf{1 . 3}$ & $-\mathbf{7 . 7}$ & $-\mathbf{8 . 8}$ & $\mathbf{0 . 2}$ \\
July & & & & \\
LGM & $13.9(0.1)$ & $16.1(0.5)$ & $10.1(0.3)$ & $-11.7(0.5)$ \\
MIS3-sta & $16.4(0.1)$ & $22.8(0.6)$ & $12.9(0.4)$ & $-7.7(0.5)$ \\
MIS3-sta vs LGM & $\mathbf{2 . 5}$ & $\mathbf{6 . 7}$ & $\mathbf{2 . 8}$ & $\mathbf{4 . 0}$ \\
MIS3-int & $16.7(0.1)$ & $23.2(0.5)$ & $13.6(0.3)$ & $-6.8(0.5)$ \\
MIS3-int vs sta & $\mathbf{0 . 3}$ & $\mathbf{0 . 4}$ & $\mathbf{0 . 7}$ & $\mathbf{0 . 9}$ \\
MIS3-HE & $15.6(0.1)$ & $17.0(0.7)$ & $7.8(0.3)$ & $-8.1(0.6)$ \\
MIS3-HE vs sta & $-\mathbf{0 . 8}$ & $-\mathbf{5 . 8}$ & $-\mathbf{5 . 1}$ & $-\mathbf{0 . 4}$ \\
\hline
\end{tabular}

\section{MIS3-sta and MIS3-int climates vs. LGM climate}

\subsection{Atmosphere}

\subsubsection{Temperature}

Globally, our modelled MIS 3 climates are significantly warmer than LGM, especially during boreal summer (see Fig. 3 and Table 2). The global mean July surface air temperature (SAT) anomalies compared to LGM are $+2.5 \pm 0.2^{\circ} \mathrm{C}$ ( \pm 0.2 means $2 \sigma=0.2$ ) for MIS3-sta and $+2.8 \pm 0.4^{\circ} \mathrm{C}$ for MIS3-int. Moreover, the Northern Hemisphere (NH) features stronger warm anomalies than the Southern Hemisphere (SH) with NH July SAT anomalies of $+3.5 \pm 0.4^{\circ} \mathrm{C}$ for MIS3-sta and $3.8 \pm 0.4^{\circ} \mathrm{C}$ for MIS3-int, whereas they are $+0.9 \pm 0.4^{\circ} \mathrm{C}$ and $+1.1 \pm 0.4^{\circ} \mathrm{C}$ respectively for the SH January SAT anomalies. As can be seen from Fig. 3f, the differences in SAT between MIS3-int and MIS3-sta are relatively small (mostly below $1{ }^{\circ} \mathrm{C}$ ), and in many locations not significant to the $99 \%$ confidence level. However, when upscaling to continental size or ocean basin size, some SAT differences are significant (see Table 2). We therefore compare MIS3- sta with LGM and only discuss the statistically significant differences between MIS3-sta and MIS3-int.

The high-latitude summers are vigorously warmer in MIS3-sta than in LGM, as is depicted in Fig. 3c. In the NH, the July SAT anomaly is $+5^{\circ} \mathrm{C}$ to more than $+15^{\circ} \mathrm{C}$ warmer in MIS3-sta. Regionally, the strongest warm anomalies are found in northern Russia, the Arctic Ocean $\left(+5^{\circ} \mathrm{C}\right.$ to $+15^{\circ} \mathrm{C}$, especially in September, not shown), the Nordic Seas, and Canada and Alaska. In the SH the warm anomalies are somewhat attenuated, with January SAT anomalies of $+3^{\circ} \mathrm{C}$ to $+10^{\circ} \mathrm{C}$ over coastal Antarctica (see Fig. 3d). For that month, the Labrador Sea and parts of the Artic Ocean and Nordic Seas show the largest positive anomalies of up to $+25^{\circ} \mathrm{C}$.

Some mid-latitudinal regions experience much warmer temperatures in MIS3-sta during summer as well (see Fig. 3c), with $+3^{\circ} \mathrm{C}$ to $+10^{\circ} \mathrm{C}$ and more in the NH. Over the $\mathrm{NH}$ mid-latitude oceans, however, the strongest warm anomaly is confined to $+3.5^{\circ} \mathrm{C}$ over the North Atlantic sector. In comparison, in the SH, January and July anomalies of $+1^{\circ} \mathrm{C}$ to $+5^{\circ} \mathrm{C}$ occurred over Antarctica and the Southern Ocean respectively. Only weak, and in many areas not significant SAT differences are noted elsewhere in the SH mid 
a)

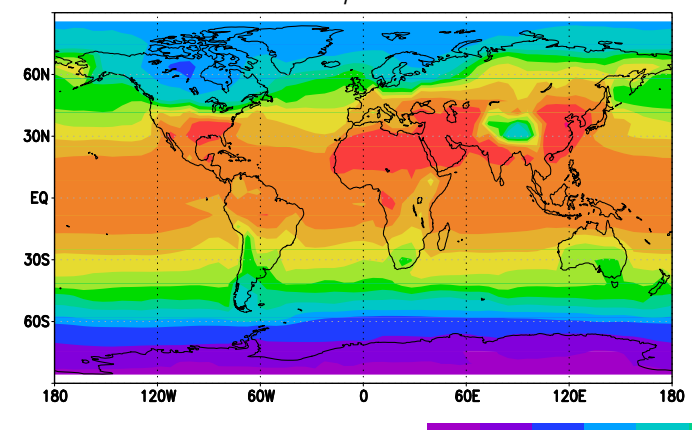

b)

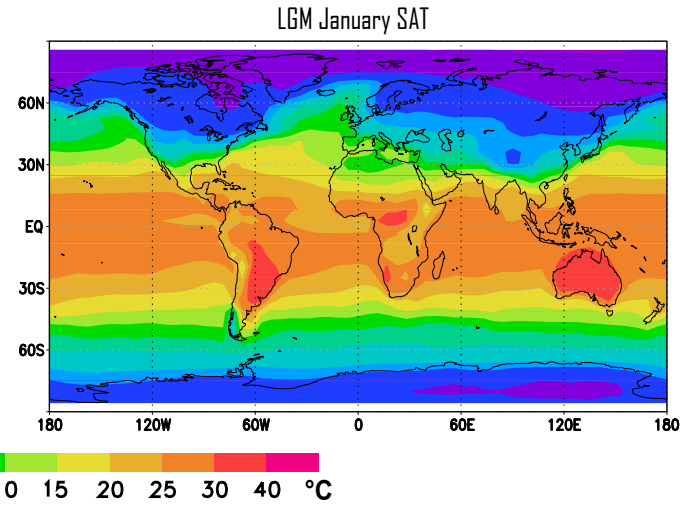

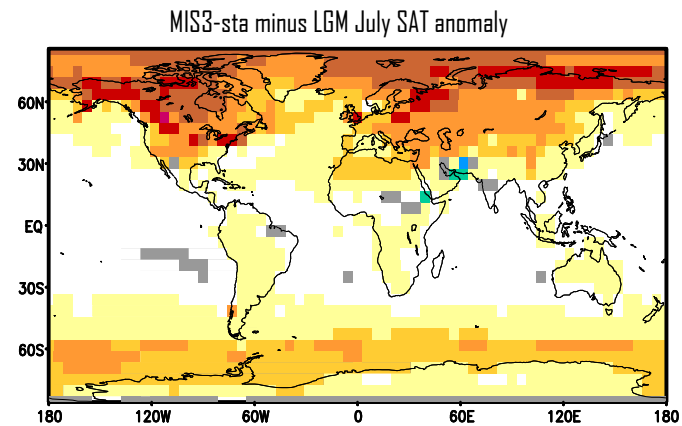

e)

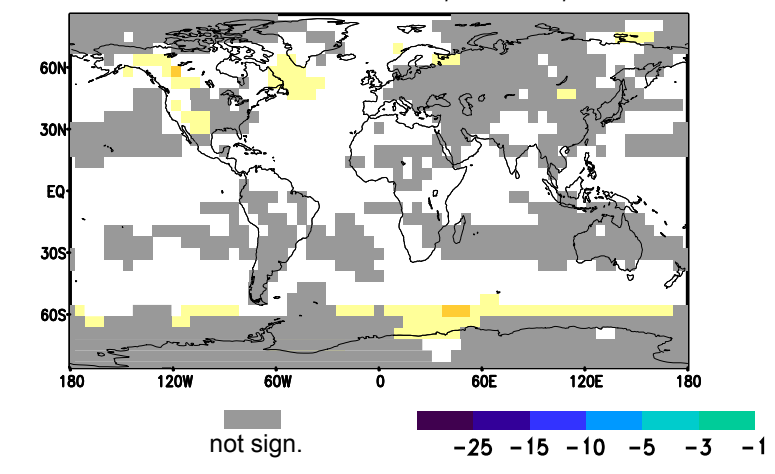

d)

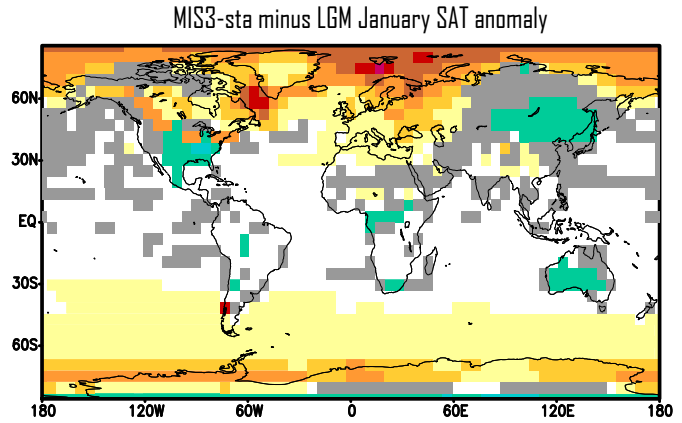

f)

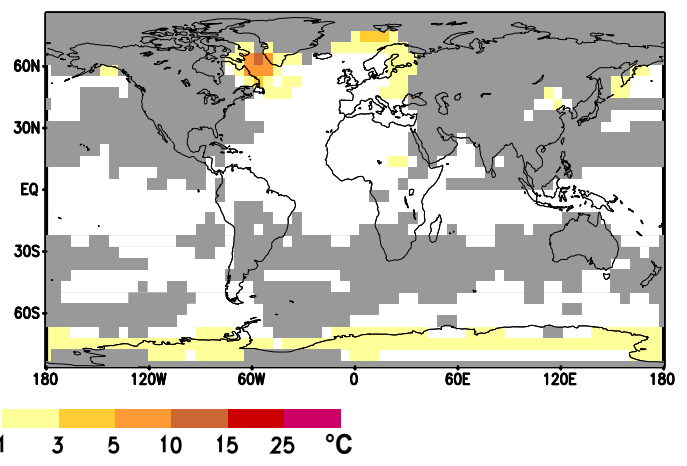

g)

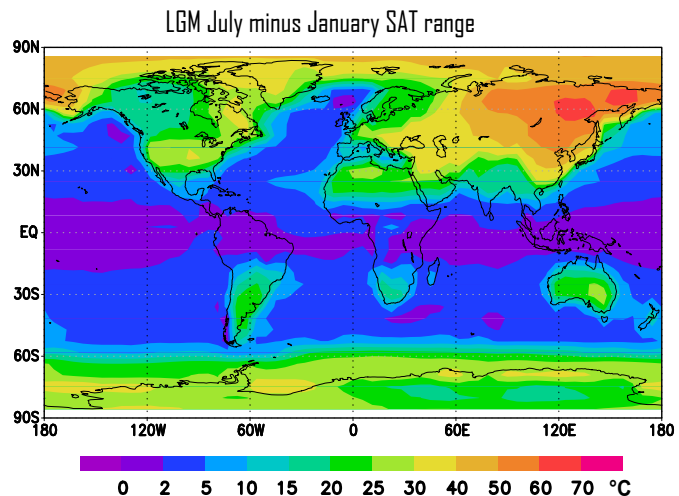

h)

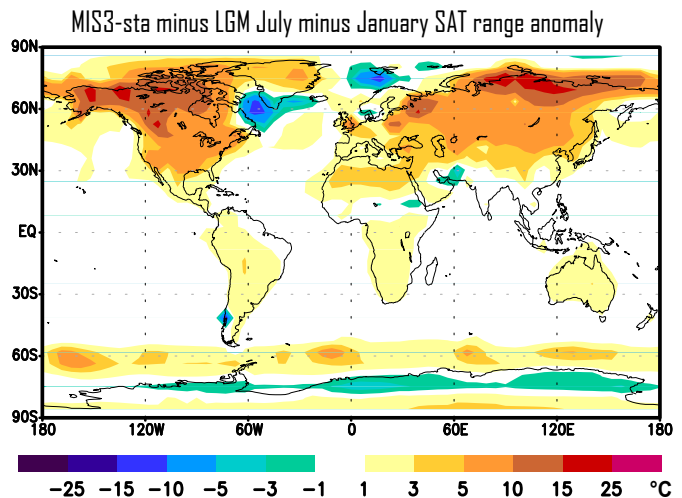

Fig. 3. (a-f) July (left panels) and January (right panels) SATs for LGM (a and b), MIS3-sta minus LGM anomaly (c and d), MIS3-int minus MIS3-sta anomaly (e and f); (g) LGM seasonal SAT range (July minus January); (h) Seasonal SAT range anomaly for MIS3-sta minus LGM. 
latitudes (see Fig. 3d). Winters show contrasting response to the imposed forcings and boundary conditions in the mid latitudes. Whereas the entire western Eurasia, part of the North Atlantic and the mid latitude SH are warmer in January in our MIS3-sta simulation than in LGM, no significant signal is registered in most other regions. Two exceptions are the United States east of the Rocky Mountains and Southern Siberia, which exhibit some cooler January SATs.

Further away from the poles, July SAT anomalies of $+1^{\circ} \mathrm{C}$ to as much as $+5^{\circ} \mathrm{C}$ in the $\mathrm{NH}$ continental subtropics are found. Arid and semi-arid regions of northern Africa and in central and western China experience the strongest positive signal. Over the oceans, warming is mostly limited to $+1^{\circ} \mathrm{C}$ (see Fig. 2c). Interestingly, January anomalies are negative over the Australian deserts, and some subtropical SH locations as well as equatorial Africa. The remaining subtropical and all tropical regions, with the exception of certain patches over land, showed warming of less than $+1^{\circ} \mathrm{C}$.

Subtracting the absolute values of the January from the July SATs, we obtain an approximation of the seasonal range and hence the continentality. As can be seen from Fig. 3g, in our LGM simulation, the range is usually smaller over the ocean than over the continent at any latitude, and in both cases becomes larger moving pole wards from the equator (less than $2^{\circ} \mathrm{C}$ ) to the high latitudes (from about $20^{\circ} \mathrm{C}$ to as much as $70^{\circ} \mathrm{C}$ ). Over the continents, one may observe an increase towards the east in the mid latitudes. Over the ice sheets, the seasonal temperature range is usually reduced (to about $20^{\circ} \mathrm{C}$ ) compared to the latitudinal average. The anomaly of MIS3-sta minus LGM (Fig. 3h) shows a clearly larger seasonal range over much of the $\mathrm{NH}$, especially in the high latitudes. Notable exceptions are the Labrador Sea and parts of the Nordic Seas - where the SAT seasonality range is strongly reduced. Over the $\mathrm{SH}$, not much change is noted north of $55^{\circ} \mathrm{S}$, whereas relatively strong differences appear over the Southern Ocean and coastal Antarctica for our JulyJanuary approximation.

When comparing MIS3-int to MIS3-sta finally (Fig. 3e, f), the only regions showing significantly warmer winters and summers were located around Antarctica and above the Labrador and Nordic Seas, respectively over NW Canada, and to a lesser extent than in January also the Labrador Sea. Overall, as reflected by the global annual mean SATs, MIS3int was slightly warmer than MIS3-sta by $+0.4^{\circ} \mathrm{C}$, both in January and July (see Table 2).

\subsubsection{Northern Hemisphere atmospheric circulation and global precipitation}

In the NH mid- and high-latitudes, winter heralds a strong cyclonic regime over the north-eastern Atlantic and the Nordic Seas and over the Gulf of Alaska and the Bering Strait at the $800 \mathrm{hPa}$ level in our LGM simulation (Fig. 4a). Conversely, an anticyclonic wind flow prevails over Canada, Greenland,
Scandinavia, the eastern North Atlantic and western Mediterranean and Central Asia.

Compared to LGM, we note for MIS3-sta a weaker anticyclonic regime over Scandinavia and down to the mid latitudes of the eastern North Atlantic and over North America and the Pacific north of $45^{\circ} \mathrm{N}$ (Fig. 4b). The geopotential height is reduced by down to $-500 \mathrm{~m}^{2} \mathrm{~s}^{-2}$. Around this anomalous low, an increase in clockwise wind motion of up to $60 \%$ occurs between the anomalous low and anomalous highs over Greenland and Northern Russia. A larger anomalous cyclonic cell centred over the Bering Sea, stretches westwards to eastern Siberia and connects to the European cell to the east. These changes compared to LGM result in enhanced westerlies between $35^{\circ} \mathrm{N}$ and $60^{\circ} \mathrm{N}$ over the Pacific and at around $40^{\circ} \mathrm{N}$ over North America, stronger south-westerlies over South-western Europe and South-eastern Scandinavia. In addition, south-westerlies south of Greenland and Iceland into the Nordic Seas nearly disappeared. Finally stronger easterlies are seen north of Europe at around $80^{\circ} \mathrm{N}$.

At the $200 \mathrm{hPa}$ level (Fig. 4c, d) - representing the high troposphere where the Polar Front Jet is strongest - the anomalous cyclonic cells over the mid- and high-latitudes of the NH show similarities in location and strength to the $800 \mathrm{hPa}$ level. Anomalous lows are centred over the eastern North Atlantic and the North Pacific. The latter has a more southern location than the anomalous Bering Low at $800 \mathrm{hPa}$ and stretches into south-western Asia. The geopotential height is higher than at LGM near the North Pole, over Greenland and Northern Eurasia. Wind patterns were in general less affected than at $800 \mathrm{hPa}$ in relative terms, except for the Arctic and Northern Siberia (-40\% down to $-100 \%)$ with anomalous easterly winds, and an increased westerly jet in many places at $30^{\circ} \mathrm{N}(0 \%$ to $+40 \%)$. All in all, no major reorganisation of the Polar Front Jet takes place between MIS3-sta and LGM.

The annual sum of precipitation is substantially higher in MIS3-sta than in LGM (Fig. 4f) over most of the northern tropics including the Sahel and the arid or semi-arid regions of south-west and central Asia (more than $+600 \mathrm{~mm}$ over Pakistan). Additionally, a significant increase is noted over parts of the Arctic, the North Pacific and North Atlantic. It was lower, however, over the British Isles and the Irminger Sea, over the US plains and eastern Rocky Mountains, and the equatorial Pacific. Apart from the above regions, a slight, patchy increase is seen over much of the extra-tropical SH. In conclusion, the global mean annual sum of precipitation is more elevated in MIS3-sta, with spatial changes rather confined to the tropics and the extra-tropical NH. No notable differences are found, however, between MIS3-sta and MIS3int.

\subsection{Vegetation}

The clearest difference in vegetation pattern between LGM and MIS3-sta is a significant increase in vegetation over 


\section{LGM}

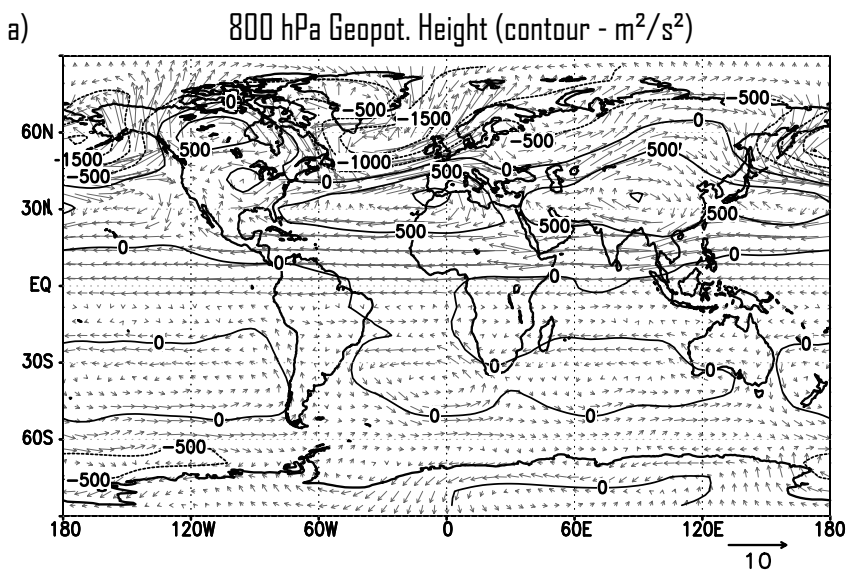

c) $200 \mathrm{hPa}$ Geopat. Height (cantour $\left.-\mathrm{m}^{2} / \mathrm{s}^{2}\right)$

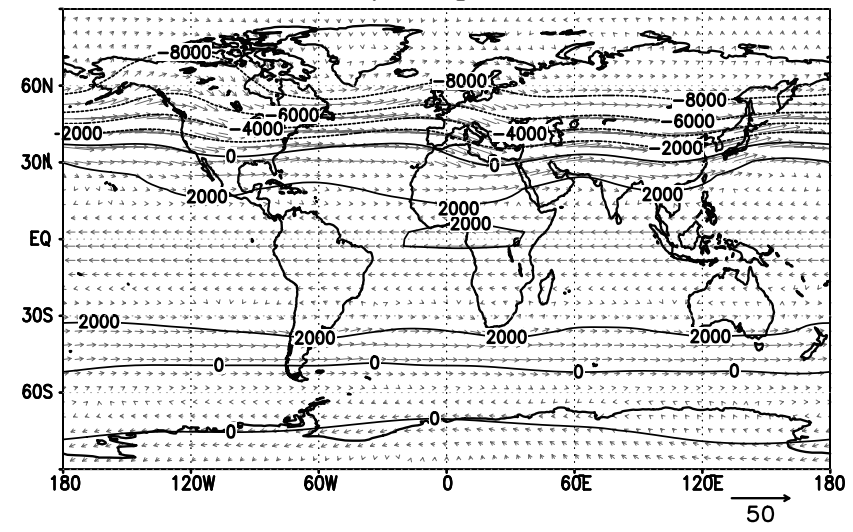

e)

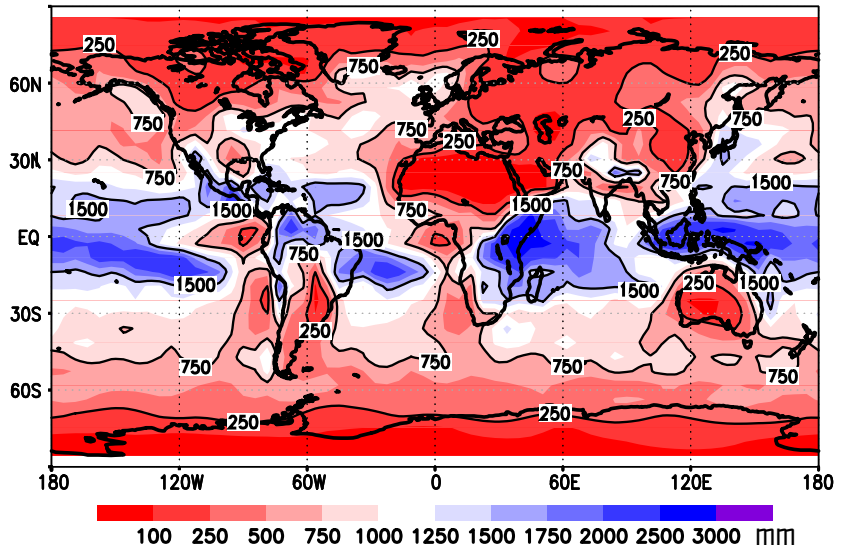

\section{MIS3-sta minus LGM anomaly}

b) $800 \mathrm{hPa}$ Geapat. Height (contour - $\mathrm{m}^{2} / \mathrm{s}^{2}$ ) \& wind norm (colour - \%)

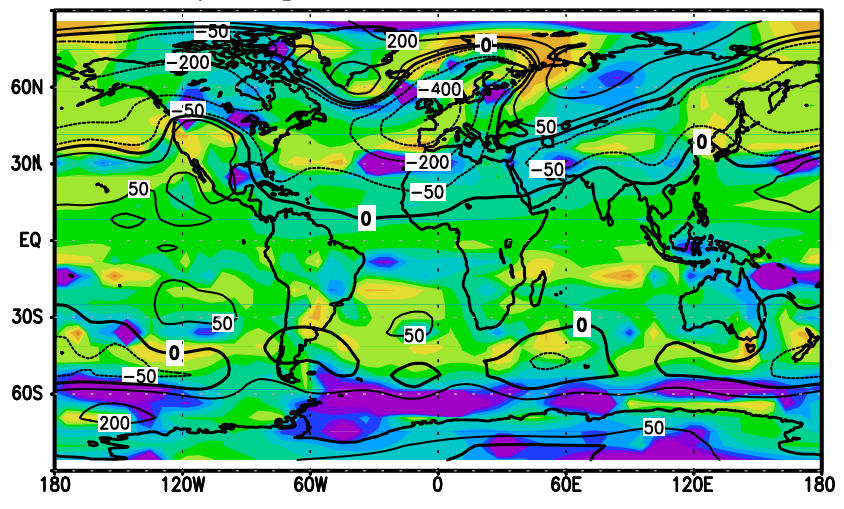

d) $200 \mathrm{hPa}$ Geapot. Height (contour - $\mathrm{m}^{2} / \mathrm{s}^{2}$ ) \& wind norm (colour - \%)
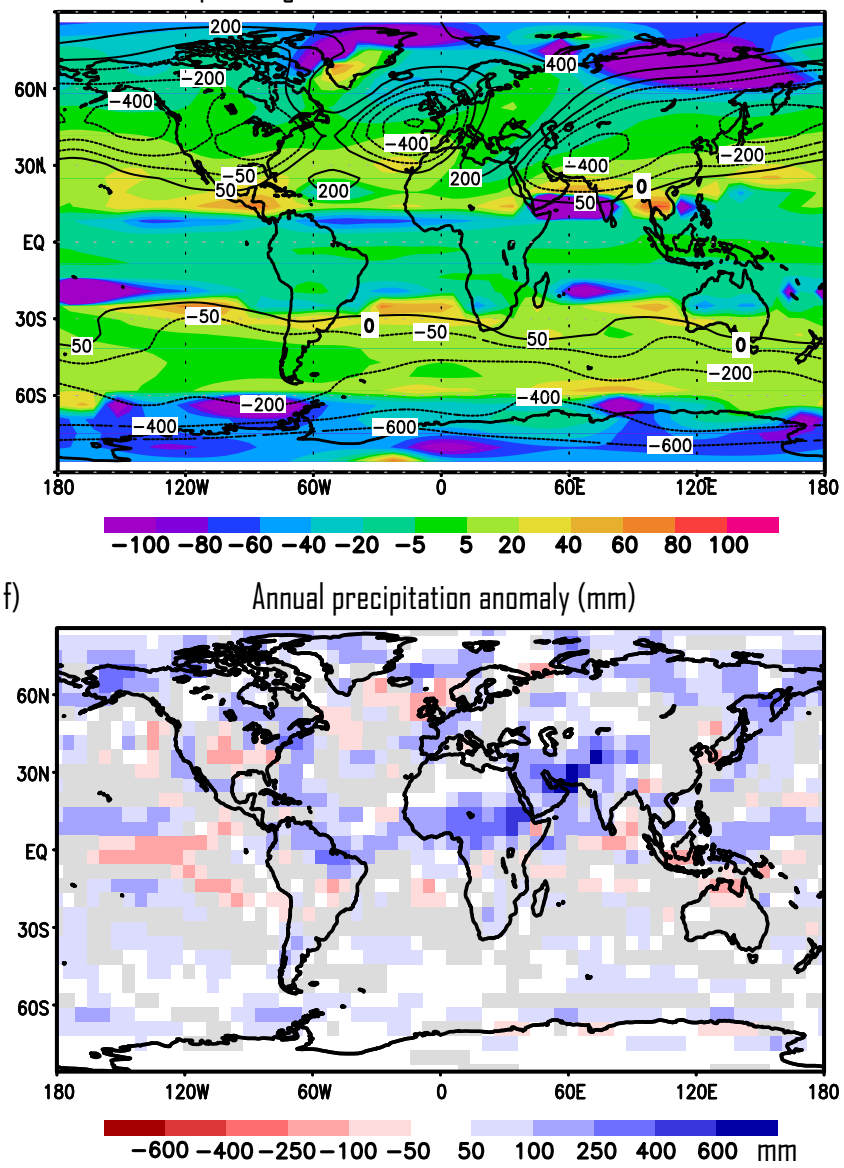

Fig. 4. The LGM and MIS3-sta atmospheric circulation and precipitation: (a) $800 \mathrm{hPa}$ and (c) $200 \mathrm{hPa}$ level LGM DJF Geopotential height (contour lines, in $\mathrm{m}^{2} \mathrm{~s}^{-2}$ ) and wind vectors $\left(\mathrm{m} \mathrm{s}^{-1}\right.$ ), representing the near surface and high troposphere atmospheric circulation resp.; (b) $800 \mathrm{hPa}$ and (d) $200 \mathrm{hPa}$ level MIS3-sta minus LGM DJF Geopotential height anomalies (contour lines, in $\mathrm{m}^{2} \mathrm{~s}^{-2}$ ) and the wind norm anomalies (colour scale, \% change in wind speed); (e) LGM and (f) MIS3-sta minus LGM anomaly of the annual sum of precipitation (mm). Grey areas indicate no significant differences. 

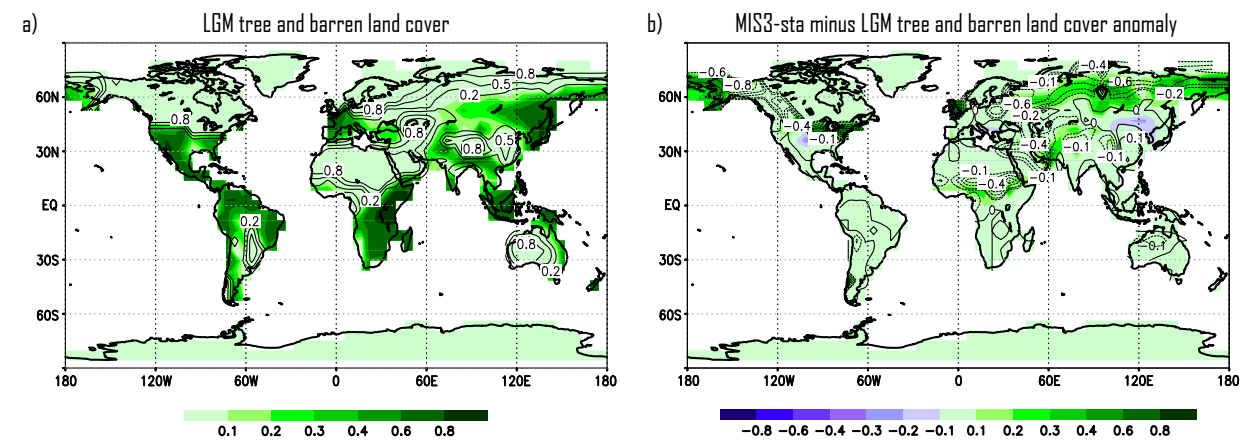

Fig. 5. (a) LGM and (b) MIS3-sta minus LGM anomaly of the fraction of tree cover (colour scale) and barren land cover (contour lines).

Eurasia and Alaska around $60^{\circ} \mathrm{N}$ for MIS3-sta, with more than $+20 \%$ of tree cover - except over north-eastern Europe (Fig. 5a, b). Similarly, a reduction of barren land area by $40 \%$ is simulated over SW Asia as well as a $5^{\circ}$ to $10^{\circ}$ northward retreat of the southern border of Sahara desert. In addition, a retreat of polar desert east of the Canadian Rocky Mountains and Northern Eurasia is noted as well as an increase in tree cover in the north-eastern quarter of the United States at the expense of barren land. As opposed to the Sahel, lower tree and higher desert cover are found in the central plains of the United States, over the eastern Mediterranean region, Mongolia and north-eastern China.

\subsection{Ocean}

Whereas the surface circulation in the oceans remains relatively unchanged between LGM and MIS3-sta, the Atlantic meridional overturning circulation (MOC) faces some changes. The clearest change involves a shift of the main deep convection sites in the North Atlantic sector (Fig. 6a, b). In MIS3-sta, deep convection is enhanced in the Labrador Sea and the Nordic Seas, whereas it is reduced in the North Atlantic Ocean south of Iceland and Greenland as compared to LGM (compare Figs. 6a and b). This shift in convection sites resembles the shift from LGM to the pre-industrial climate (Roche et al., 2007). However, no associated significant change in the maximum of Atlantic meridional overturning results from this shift, being around $33 \mathrm{~Sv}$ in both simulations (see Table 3). Concomitantly, no significant change in southward NADW export at $20^{\circ} \mathrm{S}$ in the Atlantic is observed, being around $16 \mathrm{~Sv}$ in both simulations.

Alongside deep convection, we observe a reduced sea-ice concentration in the Labrador Sea and the Nordic Seas in MIS3-sta, both in winter (March) and summer (September) (Fig. 7a-f). The annual mean NH ice-cover decreases from $11.2 \times 10^{6} \mathrm{~km}^{2}$ for LGM to $9.2 \times 10^{6} \mathrm{~km}^{2}$ for MIS3-sta (see Table 3). Conversely, in the Southern Ocean, a vast reduction of the sea-ice cover takes place in MIS3-sta - annual mean $23.5 \times 10^{6} \mathrm{~km}^{2}$ for LGM down to $18.7 \times 10^{6} \mathrm{~km}^{2}$ for MIS3sta. As can be seen from Fig. 7h, k, during winter (Septem- ber) and summer (March) the sea-ice at the northward edges - around $55^{\circ} \mathrm{S}$ and $60^{\circ} \mathrm{S}$ respectively - retreats southward in MIS3-sta.

Apart from a slight decrease in Antarctic bottom water (AABW) formation in MIS3-int versus MIS3-sta and versus LGM, no substantial differences in overturning strength between the three simulations occur. Consequently, the northward oceanic heat flux remains relatively unchanged in magnitude, being about $0.3 \mathrm{PW}$ in the three simulations (Table 3).

With no significant reduction in sea-ice extent between MIS3-sta and MIS3-int, the relatively unaltered surface ocean circulation and Atlantic meridional overturning circulation, sea surface temperatures (SST) do not differ between MIS3-sta and MIS3-int, except in locations with seaice cover changes. The annual mean SSTs of the Southern Ocean $\left(50-65^{\circ} \mathrm{S}\right)$ are $1.2^{\circ} \mathrm{C}$ for MIS3-sta and $1.5^{\circ} \mathrm{C}$ for MIS3-int while over the North Atlantic sector $\left(60^{\circ} \mathrm{W}-12^{\circ} \mathrm{E}\right.$, $30-72^{\circ} \mathrm{N}$ ) they are $11.4^{\circ} \mathrm{C}$ and $12.8^{\circ} \mathrm{C}$, respectively. In both regions the SST warming of MIS3-int versus MIS3-sta reflects the atmospheric surface temperatures.

\section{Discussion}

4.1 MIS 3 base climates warmer than LGM with enhanced seasonality

In our model, imposing boundary conditions characteristic of MIS 3 creates a substantially warmer glacial climate than the LGM climate. NH SATs diverge more strongly from LGM during summers than during winters. The enhanced seasonality in the NH is a consequence of the orbital configuration, allowing for more insolation over the $\mathrm{NH}$ during summer $\left(+50 \mathrm{~W} \mathrm{~m}^{-2}\right.$ or $+10 \%$ in June at $60^{\circ} \mathrm{N}$, Fig. 1) and less during winter $\left(-6 \mathrm{~W} \mathrm{~m}^{-2}\right.$ or $-22 \%$ in December at $60^{\circ} \mathrm{N}$, Fig. 1). The second external factor causing the milder MIS 3 conditions was the reduced surface albedo due to smaller ice sheets and less extensive sea-ice cover. Less extensive continental ice cover causes the surface albedo to decrease, while lower ice sheet topography directly increases local SATs and therefore the global mean SAT. As can be expected, with 


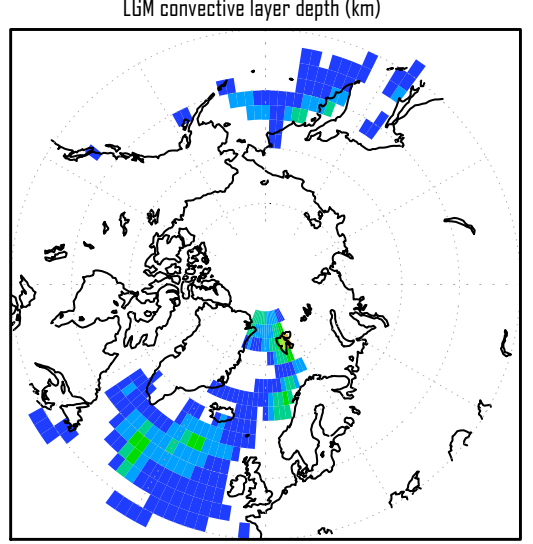

b)

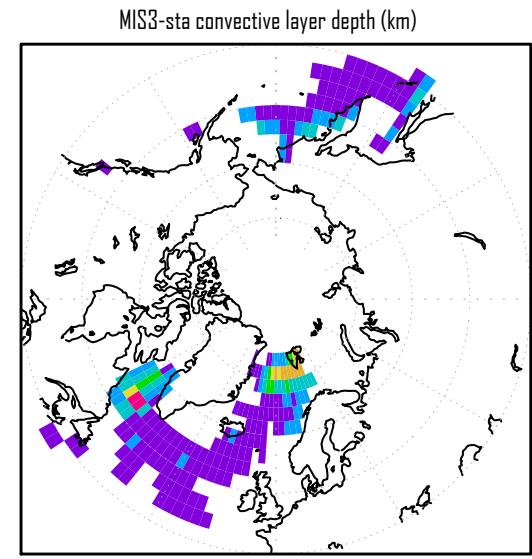

$\begin{array}{lllllllll}0.3 & 0.6 & 0.9 & 1.2 & 1.5 & 1.8 & 2.1 & 2.4 & \mathrm{~km}\end{array}$

Fig. 6. (a) LGM and (b) MIS 3-sta maximum convective layer depth (km) in the NH oceans.

Table 3. Oceanic circulation changes between LGM, MIS3-sta, MIS3-int and MIS3-HE.

\begin{tabular}{lllll}
\hline & LGM & MIS3-sta & MIS3-int & MIS3-HE \\
\hline NH sea-ice cover $\left(10^{6} \mathrm{~km}^{2}\right)$ & 11.2 & 9.2 & 9.1 & 12.9 \\
SH sea-ice cover $\left(10^{6} \mathrm{~km}^{2}\right)$ & 23.5 & 18.7 & 18.0 & 18.4 \\
NADW export in the Atlantic at $20^{\circ} \mathrm{S}(\mathrm{Sv})$ & 16.3 & 16.3 & 16.1 & 2.8 \\
NADW production (Sv) & 33.0 & 33.5 & 33.7 & 3.3 \\
NADW production in Nordic Seas (Sv) & 2.2 & 2.7 & 2.9 & 0.3 \\
AABW export in the Atlantic at $20^{\circ} \mathrm{S}(\mathrm{Sv})$ & 2.1 & 3.7 & 4.0 & 9.3 \\
AABW production $(\mathrm{Sv})$ & 35.0 & 32.2 & 30.9 & 31.8 \\
Northward oceanic heat flux at $30^{\circ} \mathrm{S}(\mathrm{PW})$ & 0.29 & 0.34 & 0.35 & -0.46 \\
SST Southern Ocean $\left({ }^{\circ} \mathrm{C}\right)$ & 0.1 & 1.2 & 1.5 & 1.4 \\
SST North Atlantic sector $\left({ }^{\circ} \mathrm{C}\right)$ & 10.3 & 11.4 & 12.8 & 7.0 \\
SST Global average $\left({ }^{\circ} \mathrm{C}\right)$ & 16.8 & 17.1 & 17.4 & 16.5 \\
\hline
\end{tabular}

small differences in GHG and dust forcing, our MIS3-sta and MIS3-int simulations feature virtually the same climate. This implies that differences in atmospheric GHG and dust concentration during MIS 3 did not affect the temperatures in the same order of magnitude as ice sheet and orbital configuration do.

Sea-ice cover contributed to an MIS 3 climate different from LGM. In the high latitude oceans, sea-ice was less extensive under elevated atmospheric temperatures and SSTs. Poleward retreat of sea-ice involved a reduction in both local and global albedo, which further enhanced the warming in MIS 3. In the Labrador Sea and Nordic Seas sea-ice was strongly reduced, both in winter and summer. Therefore, deep convection near the sea-ice margin could shift from the open waters of the North Atlantic at LGM to these regions. Where NADW production took place, local additional surface heating resulted.
Finally, the surface albedo was effectively reduced over the NH continents through enlarged forestation and general retreat of the deserts, especially polar deserts. Increased precipitation, higher summer temperatures and retreat of the ice sheets allowed for denser plant cover in mid and high latitudes. In turn, in otherwise semi-arid and arid areas, plant cover could help enhance the hydrological cycle. This feedback mechanism is not computed, however, since our vegetation model is only coupled to the atmospheric model through temperature as input and surface albedo as output. For the northern tropics of Africa, the desert retreat associated with enhanced precipitation signalise a northward shift and intensification of the intertropical convergence or a combination of both. In case of a northward shift, the increased precipitation in the northern tropics is accounted for, but the precipitation does not change over the southern tropics. In the case of intertropical convergence intensification, an increase in rainfall is expected on both sides of the Intertropical 
a)

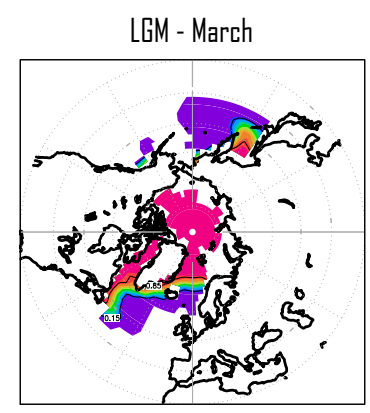

d)

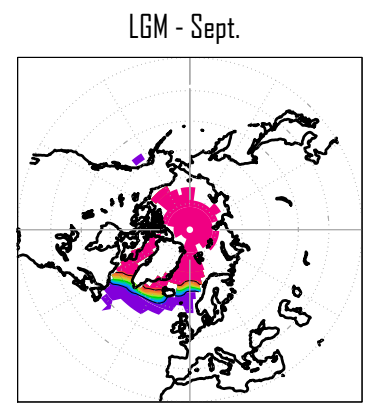

g)

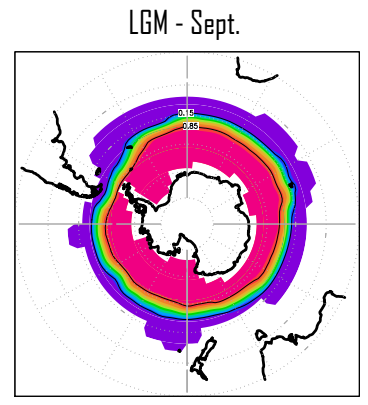

j)

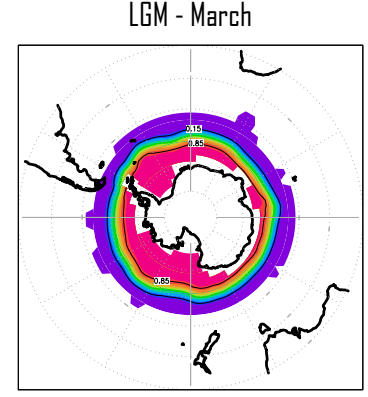

$\begin{array}{lllllllll}0.1 & 0.2 & 0.3 & 0.4 & 0.5 & 0.6 & 0.7 & 0.8 & 0.9\end{array}$ b)

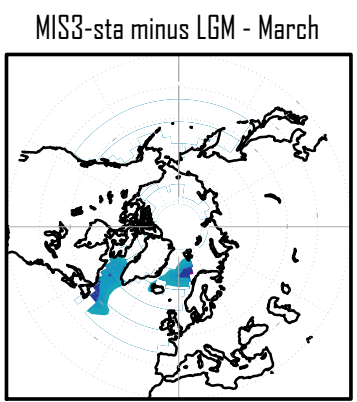

e)

MIS3-sta minus LGM - Sept.

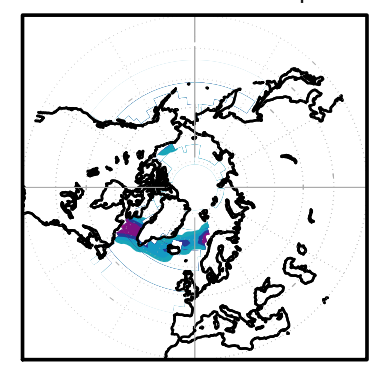

h)

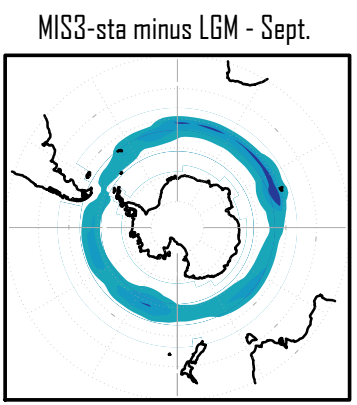

k)

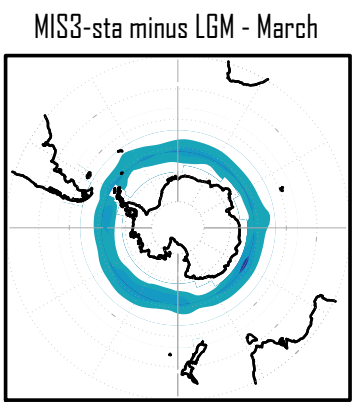

c)

MIS3-int minus MIS3-sta - March

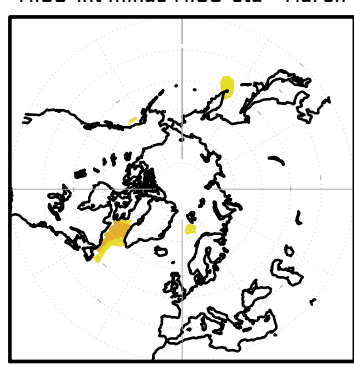

f)

MIS3-int minus MIS3-sta - Sept.

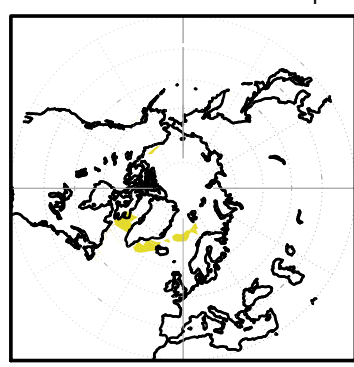

i)

MIS3-int minus MIS3-sta - Sept.

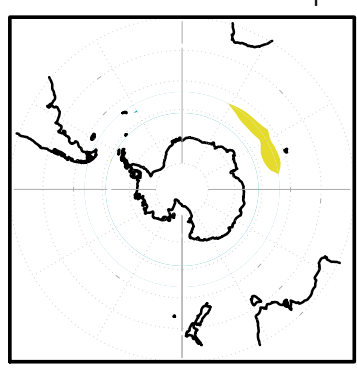

l)

MIS3-int minus MIS3-sta - March

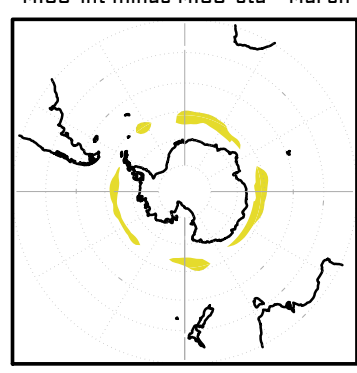

$\begin{array}{llllllllll}-0.9 & -0.7 & -0.5 & -0.3 & -0.1 & 0.1 & 0.3 & 0.5 & 0.7 & 0.9\end{array}$

Fig. 7. LGM (left panels), MIS 3-sta minus LGM anomaly (middle panels), and MIS3-sta minus MIS3-int anomaly for the NH and SH of the March (a-c and $\mathbf{j}-\mathbf{l})$ and September (d-f and $\mathbf{g}-\mathbf{h})$ sea-ice concentration. The 0.15 contour line was used by Roche et al. (2007) to allow for easy comparison with the sea-ice extent to the data of data of Gersonde et al. (2005). The 0.85 contour line approximates the limit of the extent of continuous ice versus pack ice. 
Table 4. Northern Hemisphere $-30^{\circ} \mathrm{N}$ to $90^{\circ} \mathrm{N}$ - winter and summer SATs (in ${ }^{\circ} \mathrm{C}$ ) for MIS3-sta with $56 \mathrm{ka} \mathrm{BP}, 32 \mathrm{ka} \mathrm{BP}$ and $21 \mathrm{ka}$ BP versus LGM.

\begin{tabular}{lllll}
\hline & Jan & Dec-Jan-Feb & Jul & Jun-Jul-Aug \\
\hline MIS3-sta & -10.2 & -9.3 & 17.4 & 17.3 \\
MIS3-sta-32k & -10.3 & -9.4 & 16.5 & 16.2 \\
MIS3-sta-21k & -10.2 & -9.0 & 14.9 & 14.6 \\
LGM & -12.2 & -11.8 & 11.7 & 10.2 \\
\hline
\end{tabular}

Convergence Zone, which is not the case for the southern side. We argue for a combination of both in a warmer climate with more vigorous $\mathrm{NH}$ warming.

4.2 Orbital insolation forcing drives the enhanced seasonality during MIS 3

To further study the impact of insolation on the climate during MIS3, we perform two sensitivity experiments identical to MIS3-sta, but with orbital parameters for $21 \mathrm{ka} \mathrm{BP}$ and $32 \mathrm{ka} \mathrm{BP}$. We have chosen $21 \mathrm{ka}$ for the insolation to be equal to LGM state and $32 \mathrm{ka}$ as, after this date, DO events became less frequent. Together with the $56 \mathrm{ka}$ insolation of the control experiment (MIS3-sta), we nearly cover the full range of Northern Hemisphere insolation changes during MIS 3.

The spatial pattern of the enhanced $\mathrm{NH}$ seasonality found in our MIS 3 experiments compared to LGM correlates strongly with the orbital insolation forcing. Here, we show the existence of a causal relation and quantify the climatic impact of this forcing. In MIS3-sta, $56 \mathrm{ka} \mathrm{BP}$ insolation results in warmer $\mathrm{NH}$ summers in most locations, especially in the high latitudes, while winter temperatures are less affected. In the $\mathrm{SH}$, insolation does not differ so strongly between $56 \mathrm{ka} \mathrm{BP}$ and $21 \mathrm{ka} \mathrm{BP}$. On Fig. 1 the $60^{\circ} \mathrm{N}$ and $60^{\circ} \mathrm{S}$ June and December insolation anomalies compared to present-day are depicted for 70-0 ka BP. As can be seen, $\mathrm{NH}$ summer insolation rises from a minimum $(\sim 80 \mathrm{ka} \mathrm{BP})$ to a maximum around $60 \mathrm{ka}$ BP, followed by a gradual decline till $40 \mathrm{ka} \mathrm{BP}$ and a steady decline until a second minimum around $25 \mathrm{ka} \mathrm{BP}$. At $60^{\circ} \mathrm{N}$, the MIS3-sta June insolation is $39 \mathrm{~W} \mathrm{~m}^{-2}$ more than in the LGM simulation, while the December insolation is $6 \mathrm{~W} \mathrm{~m}^{-2}$ less, resulting in a seasonal range of $45 \mathrm{~W} \mathrm{~m}^{-2}$ more. When looking at Fig. 3h, we see a seasonal temperature range of more than $10^{\circ} \mathrm{C}$ larger in MIS3-sta than in LGM over the continents at $60^{\circ} \mathrm{N}$, suggesting a sensitivity of $\sim 1^{\circ} \mathrm{C}$ per $4 \mathrm{~W} \mathrm{~m}^{-2}$ additional incoming solar radiation, and a slight increase over the ocean. (The decrease over the Labrador Sea results from the absence of winter sea-ice, elevating winter temperatures.)

To demonstrate and further quantify the sensitivity of the MIS 3 climate to insolation changes, we compare NH SATs of LGM and MIS3-sta to MIS3-sta-21k and MIS3-sta-32k. At $32 \mathrm{ka} \mathrm{BP}$, the $60^{\circ} \mathrm{N}$ June insolation was about $492 \mathrm{~W} \mathrm{~m}^{-2}$, so $\sim 16 \mathrm{~W} \mathrm{~m}^{-2}$ less than at $56 \mathrm{ka} \mathrm{BP}$ and $\sim 23 \mathrm{~W} \mathrm{~m}^{-2}$ more than at $21 \mathrm{ka}$ BP. In our experiments, we thus expect July SATs to be the highest in MIS3-sta and the lowest in MIS3sta-21k. The July SAT anomalies of MIS3-sta-21k and MIS3-sta-32k to MIS3-sta are displayed on Fig. 8. For MIS3-sta-32k, most NH mid- and high-latitude continental locations (and the polar seas) see a significant reduction of $-1^{\circ} \mathrm{C}$ to $>-10^{\circ} \mathrm{C}$ compared to MIS3-sta, whereas some subtropical locations feature a slight, but significant warming of $+1{ }^{\circ} \mathrm{C}$ to $+3^{\circ} \mathrm{C}$. Turning to MIS3-sta-21k, we see further cooling of the same regions, plus a nearly pan-hemispheric (and possibly inter-hemispheric) expansion of cooling. The $30^{\circ} \mathrm{N}$ to $90^{\circ} \mathrm{N}$ average January, December-January-February, July and June-July-August SATs are depicted for the four simulations in Table 4. Clearly, winter temperatures remain unaffected by the insolation changes. Therefore, winter insolation changes cannot explain winter temperature differences between LGM and MIS 3. However, July SAT anomalies compared to LGM rise from $+3.1^{\circ} \mathrm{C}$ for MIS3-sta-21k to $+4.8^{\circ} \mathrm{C}$ for MIS3-sta-32k and $+5.7^{\circ} \mathrm{C}$. These temperature differences correspond to $60^{\circ} \mathrm{N}$ June insolation anomalies of $0.0 \%,+3.5 \%$ and $+6.9 \%$ respectively.

The June insolation difference between MIS3-sta and LGM at $60^{\circ} \mathrm{N}$ thus results in a July SAT rise of $+2.6^{\circ} \mathrm{C}$. The remaining $+3.1^{\circ} \mathrm{C}$ as well as the increase of January SAT by $+2^{\circ} \mathrm{C}$ may then be attributed to the remaining forcings, i.e. smaller ice sheets, higher GHG and lower dust concentrations. Interestingly, NH sea-ice extent, and, more pronounced sea-ice volume, on average approach LGM values in our MIS3-sta-21k experiment, again following the insolation changes. Moreover, sea-ice extent shows oscillatory behaviour, going from $\sim 9 \times 10^{6} \mathrm{~km}^{2}$ to $\sim 11 \times 10^{6} \mathrm{~km}^{2}$, each cycle taking $\sim 250 \pm 100$ years, revealing the instability of the Nordic Sea ice cover in this climate state.

The MIS 3 climate seems to have been very sensitive to insolation changes, at least in the model. Very few reliable terrestrial seasonal temperature reconstructions are available for MIS 3 in North America, Europe and Asia (Vandenberghe, 1992; Huijzer and Vandenberghe, 1998; Voelker et al., 2002) to allow verification of our model results and the inferred seasonality differences between LGM and MIS 3. Vandenberghe (1992) did not find evidence for enhanced seasonality during MIS 3 in The Netherlands, with summer temperatures only a few degrees warmer than at LGM, while winter temperatures were much reduced, resulting in continuous permafrost. However, Coope (1997), Helmens et al. (2007) and Engels et al. (2007) point out that, during at least one MIS 3 interstadial, warm, close to present-day summer conditions prevailed over Central England $\left(\sim 18^{\circ} \mathrm{C}\right)$ and northeast Finland $\left(\sim 13^{\circ} \mathrm{C}\right)$. These warm summers in MIS 3 over mid- and high northern latitudes are consistent with our findings. However, we obtain annual mean temperatures in those regions in our MIS3-sta experiments that are well above $0^{\circ} \mathrm{C}$, whereas the available data suggests much colder stadial conditions, i.e. permafrost over north-western Europe 

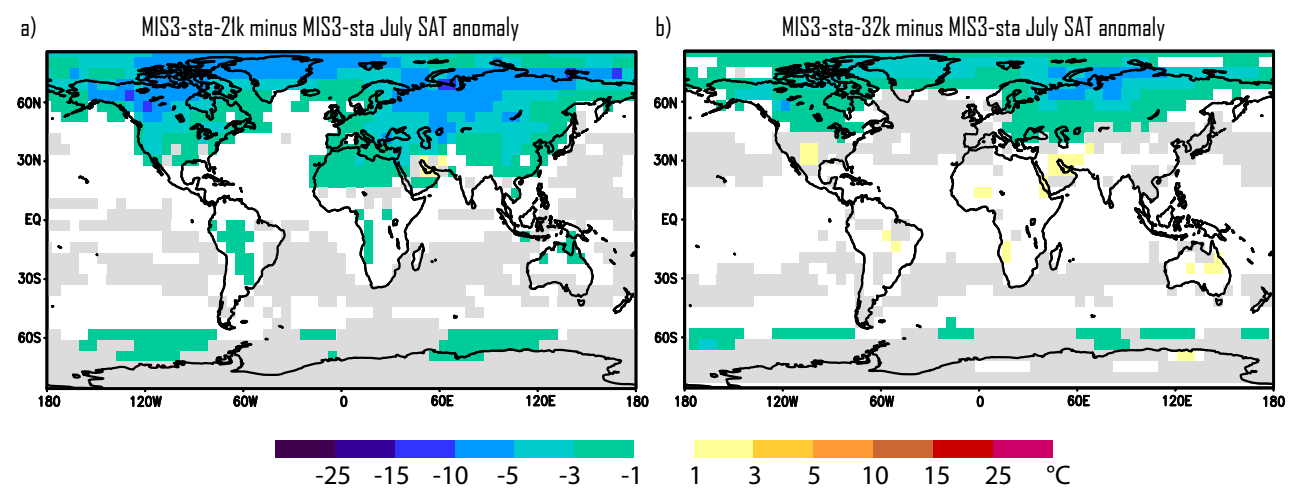

Fig. 8. (a) MIS3-sta-21k minus MIS3-sta and (b) MIS3-sta-32k minus MIS3-sta July SAT anomaly. Grey areas show no significant differences between the two simulations.

(i.e., annual mean temperature of -4 to $-8^{\circ} \mathrm{C}$, Huijzer and Vandenberghe, 1998). The warmer conditions in the model than in the data were also present in the high resolution MIS 3 simulations of Barron and Pollard (2002). Pollard and Barron (2003) suggest that the warm bias might be related to prescribed North Atlantic SSTs, which may have been too elevated to represent MIS 3. In our experiments, however, simulated SSTs remain too high under MIS 3 boundary conditions. In the next section, we therefore compare MIS3-sta to MIS3-int to try to disentangle this discrepancy between model and data.

\subsection{Comparison of the MIS3-sta and MIS3-int climates}

While both being clearly warmer than the modelled LGM, the climates of MIS3-sta and MIS3-int differ only very slightly, the latter being at most $1{ }^{\circ} \mathrm{C}$ warmer both in summer as in winter (see Fig. 3e, f). Besides slightly larger sea-ice cover in the former (Fig. 7c, f, i, 1), the oceans are nearly unaffected by the differences in GHG and dust forcings. Our MIS3-int climate may approach interstadial conditions fairly well, with a strong Atlantic THC (van Kreveld et al., 2000), relatively little sea-ice cover in the Nordic Seas (Rasmussen and Thomsen, 2004) and warm summer conditions over northern Europe (Coope, 1997; Helmens et al., 2007). However, the strong cooling in a stadial and the reduction in deep NADW formation (Dokken and Jansen, 1999) and consequently a slowdown in the Atlantic THC - are not found in our MIS3-sta experiment. We conclude that temporal variations in GHG and dust concentrations were less important during MIS 3 than other potential climate forcings. It is thus very unlikely that GHG and dust concentration changes played a major role in explaining temperature changes during MIS 3. Barron and Pollard (2002) and Pollard and Barron (2003), who did not change $\mathrm{CO}_{2}$ forcing from LGM in their simulations, concluded that the temperature difference between LGM and MIS 3 conditions registered in the records could not be explained solely by varia- tions in orbital forcing or in the Scandinavian Ice Sheet size. In contrast, decreasing North Atlantic and Nordic Seas SSTs between a warmer and a colder state to simulate an extended southward distribution of sea ice, explained part of range of temperature differences between the two states.

If GHG and dust forcings can be ruled out as primary drivers of DO climate variability, other factors need to be invoked to sufficiently alter the THC strength. Ice sheet melting and ice berg calving may hold the key to DO climate variability, if we believe the ongoing hypothesis of THC regulation of Broecker et al. (1985) and numerous other studies. A decrease in SSTs of the North Atlantic and Nordic Seas required to better mimic climatic differences between stadials and interstadials may have been possible with a reduction in THC strength. In this view, our simulations were not intended to reproduce the full amplitude of temperature difference between stadials and interstadials. We merely state that setting a realistic climate background should help discriminate mechanisms for DO events, as they were most frequent during MIS 3. With realistic prevailing initial conditions and external forcings we are likely to reduce the uncertainty of the sensitivity of the climate system to parameter changes, i.e. GHG and dust forcings on the one hand, insolation forcing on the other.

\subsection{Freshwater forcing required to mimic stadials}

To investigate the sensitivity of our MIS3-sta climate to freshwater forcing, we perform a third sensitivity experiment in which we perturb the MIS3-sta climate with a strong, additional freshwater flux in the mid-latitudes of the North Atlantic Ocean to ensure a shut down of the Atlantic THC. From a hysteresis experiment (not presented in this study), we found that in LOVECLIM, the LGM and MIS 3 sensitivity of the overall meridional overturning strength to freshwater perturbation did not differ, with a shutdown occurring at around $0.22 \mathrm{~Sv}$. Resumption of the AMOC took place at around $\mathrm{OSv}$ freshwater forcing. Our MIS 3 experiment with 
a)

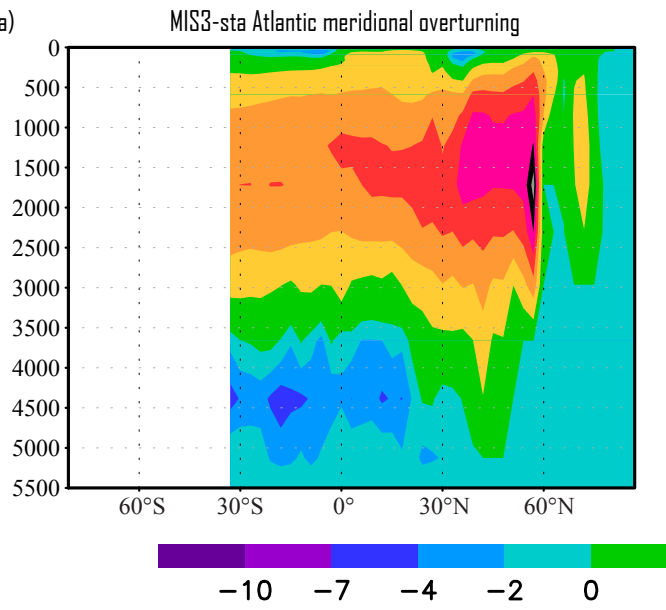

b) MIS3-HE Atlantic meridional overturning

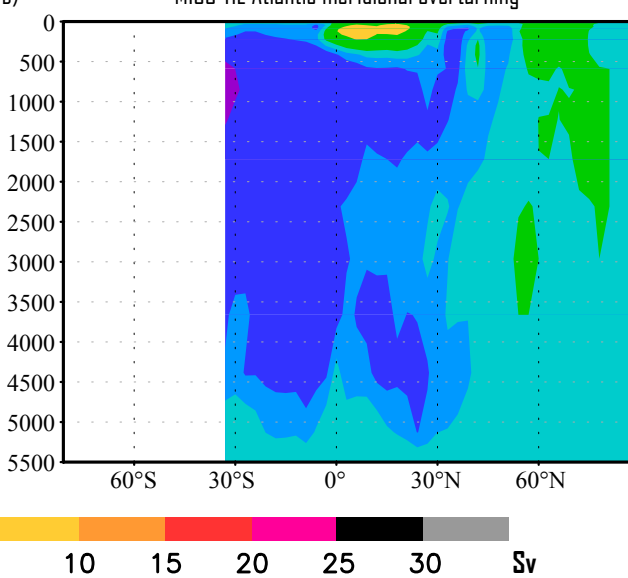

Fig. 9. (a) MIS3-sta and (b) MIS3-HE annual mean Atlantic meridional overturning (Sv). The vertical axis represents depth (m), the horizontal axis gives the latitude. Positive values mean a southward flow of a water body, while negative values imply a northward flow.

collapsed AMOC (MIS3-HE), forced with a constant 0.3Sv freshwater flux is setup as an idealized analogue for a Heinrich event. To not indefinitely decrease the global ocean's salinity in this equilibrium run, we allow for a global freshwater correction. As a result, no global sea level rise due to freshwater input is simulated and the salinity of the North Pacific increases. Here we only briefly compare climate conditions in the Atlantic sector between MIS3-HE and MIS3-sta, to ensure that the limitation of freshwater correction does not strongly affect our results.

In our MIS3-HE simulation, NADW formation is virtually absent (see Table 3). With the Atlantic MOC shut down, vigorous inflow of intermediate and deep waters from the south takes place (Fig. 9b). Compared to the Atlantic MOC in MIS3-sta (Fig. 9a), the cell transporting NADW disappears, with NADW export of less than 2Sv. Conversely, the deep cell reaches the upper layers, with northward inflow of AABW into the Atlantic of more than 9Sv while being less than $4 \mathrm{~Sv}$ in MIS3-sta. As a consequence of the shutdown Atlantic MOC, the northward oceanic heat flux drops from nearly $0.30 \mathrm{PW}$ to $-0.46 \mathrm{PW}$, implying a net southward flux instead (see Table 3).

Associated with this negative northward heat flux in the North Atlantic, a reduction of $-4.4^{\circ} \mathrm{C}$ in annual mean SST is noted over the entire region, while the Southern Ocean warms up very slightly at best (Table 3). Contrastingly, global mean annual SSTs do not change. The opposite behaviour of the North Atlantic and Southern Ocean is mirrored by the sea-ice cover. On annual basis, it increases in comparable amounts on the $\mathrm{NH}\left(+2.8 \times 10^{6} \mathrm{~km}^{2}\right)$ as it decreases in the $\mathrm{SH}\left(-2.5 \times 10^{6} \mathrm{~km}^{2}\right)$.

The oceanic response to the freshwater perturbation is reverberated by the atmosphere. In Fig. 10a, b the July and January SAT anomalies of MIS3-HE minus MIS3-sta are depicted. In both summer and winter, warming over the ice- free regions of the Southern Ocean is found, whereas vigorous cooling took place over the North Atlantic and much of the NH except for the North Pacific. For instance the winter SAT south and east of Greenland drops by up to $-25^{\circ} \mathrm{C}$ over the sea-ice. In Europe and over the Arctic Ocean, a cooling of $-3^{\circ} \mathrm{C}$ down to $-10^{\circ} \mathrm{C}$ takes place. Even in North Africa and most of Asia a cooling of more than $-1^{\circ} \mathrm{C}$ is seen. A similar, but slightly weaker cooling occurs during summer. Nonetheless, in some regions slight to substantial warming takes place, $+1{ }^{\circ} \mathrm{C}$ to $+10^{\circ} \mathrm{C}-$ e.g. over the Gulf of Alaska and offshore Siberia due to enhanced meridional overturning. While much of the $\mathrm{NH}$ winters are chilled to temperatures below or near LGM values - e.g. north-western Europe, being $10^{\circ} \mathrm{C}$ cooler versus no difference in Central Greenland, - the warmer ice-free conditions around eastern Antarctica were echoed by (slighter) warming over much of the $\mathrm{SH}$.

van Huissteden et al. (2003) validated the Stage 3 modelling results with permafrost data. Using this method, we find that our MIS3-HE matches the cold surface temperatures found in Northern Europe during stadials better than our MIS3-sta. With an inferred southern limit of continuous permafrost in Northern Europe (Huijzer and Vandenberghe, 1998 ) at around $50-52^{\circ} \mathrm{N}$, the mean annual ground temperature must not exceed $0^{\circ} \mathrm{C}$ (van Huissteden et al., 2003). In MIS3-sta, we find the $0^{\circ} \mathrm{C}$ mean annual SAT isotherm - the best proxy for ground temperature in our model - at around $70^{\circ} \mathrm{N}$ in the Nordic Seas, following the Scandinavian Ice Sheet towards the south, between $50^{\circ} \mathrm{N}$ and $55^{\circ} \mathrm{N}$ over Germany and around $55^{\circ} \mathrm{N}$ eastward of Poland (not shown). For most locations, the $0^{\circ} \mathrm{C}$ isotherm lies too far north. In contrast, for MIS3-HE we obtain a reasonable match with data, with the $0^{\circ} \mathrm{C}$ isotherm lying over Scotland $\left(55-60^{\circ} \mathrm{N}\right)$, Netherlands $\left(50-55^{\circ} \mathrm{N}\right)$, Southern Germany $\left(50^{\circ} \mathrm{N}\right)$ and at around $50^{\circ} \mathrm{N}$ over Central and Eastern Europe (not shown). 

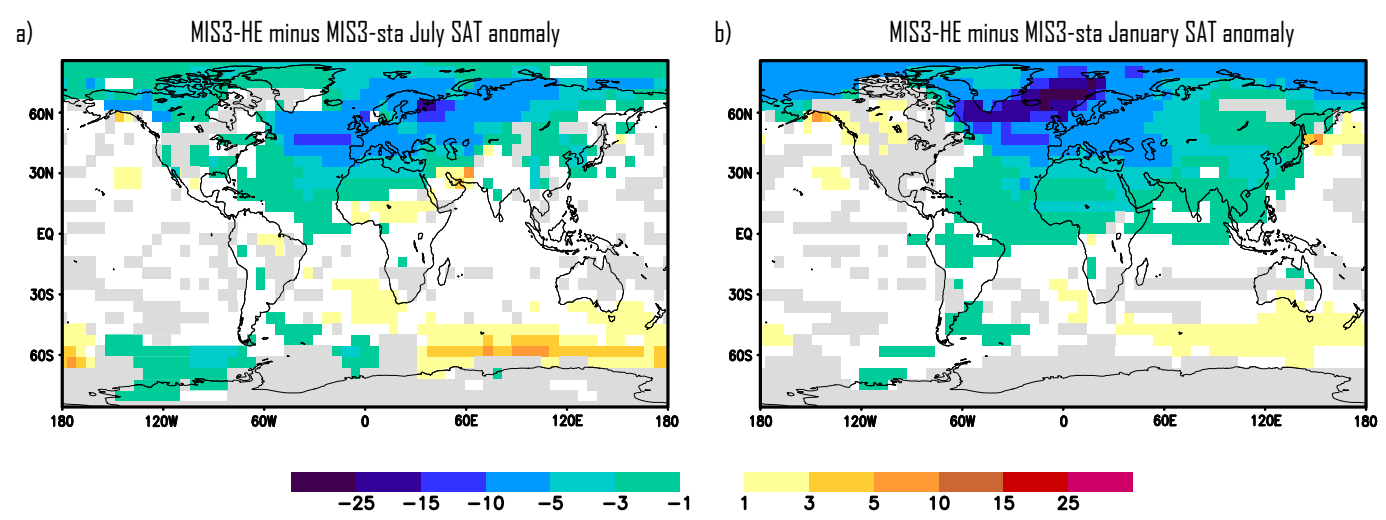

Fig. 10. (a) July and (b) January MIS3-HE minus MIS3-sta SAT anomaly. Grey areas show no significant differences between the two simulations.

The response of the world oceans to freshwater perturbations in the North Atlantic in our model is in line with previous modelling work (e.g. Knutti et al., 2004; Stouffer et al., 2006; Flückiger et al., 2008) and what is evidenced by proxy reconstructions (e.g. Dokken and Jansen, 1999). The results from our sensitivity study reveal that, in our model, a reduced stadial THC state in a background MIS 3 climate is stable, at least as long as an additional freshwater flux to the North Atlantic is maintained. With an additional $0.3 \mathrm{~Sv}$ freshwater flux to the North Atlantic, we obtain a climatic pattern similar to other simulations of Heinrich events. This is a consequence of the shutdown of the THC in our model (Fig. 9b). The redistribution of heat causes (slight) warming in the $\mathrm{SH}$, keeping global mean temperatures nearly equal to MIS3-sta or MIS3-int. Such a pattern was seen in the ice cores, and is commonly referred to as the bipolar seesaw (EPICA-community-members, 2006). Over Antarctica, the warmest peaks $\left(2^{\circ} \mathrm{C}\right)$ coincided with the coolest temperatures during stadials in Greenland and HEs in the North Atlantic.

We infer from our results and other studies (e.g. Ganopolski and Rahmstorf, 2001) that climate change resembling the observed differences between stadials and interstadials can be obtained when changing the Atlantic THC, through the strength of meridional overturning in the North Atlantic. In our MIS 3 climates, a relatively strong freshwater perturbation is required to alter the Atlantic THC. Our findings are corroborated by those of Prange et al. (2002), who found that in an ocean general circulation model, the glacial THC can only remain slowed down or shut down with a strong additional fresh water flux. In the experiments of Ganopolski and Rahmstorf (2001) based on an LGM reference climate, imposing a strong freshwater flux of $0.1 \mathrm{~Sv}$ resulted in a shutdown THC, while only a small negative forcing was imposed to obtain their warm and strong simulated interstadial THC mode, respectively small positive forcing for their cold (but strong) simulated stadial THC mode. In the stadial mode, convection was confined to the North Atlantic south of the sea-ice margin, while no NADW was formed at high latitudes. However, the LGM winter sea-ice extent may not have been as southerly in the MIS 3 background climate as during LGM. Consequently, convection would possibly not have been confined to the North Atlantic, but also present in more northern locations as the Nordic Seas as is found in our model. Ganopolski and Rahmstorf (2001) obtained Nordic Seas convection in their interstadial mode, as sea-ice retreated northward. More alike their stadial situation, in our MIS3-HE, winter sea-ice cover pushes more southward at some locations in the North Atlantic than in the LGM. In Ganopolski (2003), the simulated MIS 3 stadial states strongly resemble that of Ganopolski and Rahmstorf (2001), while using transient MIS 3 forcings as opposed to LGM forcings in the earlier study. Their results imply that the southward extent of sea-ice during stadials does not depend on insolation changes or ice sheet size. In our fully three-dimensional model, however, southward winter sea-ice extent is strongly asymmetric between the Labrador Sea and the Nordic Seas, the latter being partly ice-free in the LGM state (Roche et al., 2007). Compared to the LGM, in our model the sea-ice cover in MIS3 is less extensive, with a partly ice-free Labrador Sea in winter and a more northerly positioned sea-ice edge in the Nordic Seas. This implies that the sea-ice cover and the ocean state depend on varying glacial insolation and ice sheet size changes.

Our MIS 3 climates are warmer than the LGM, with convection sites and sea-ice extent that are more similar to present-day climate. The sensitivity of the THC to freshwater forcing is also expected to be different from LGM. For this reason, we argue that LGM should not be used to simulate DO events. Rather, one should start from a climate state obtained under MIS 3 boundary conditions. With Labrador Sea deep convection in our MIS3 simulations, the east-west structure of the Atlantic Thermohaline Circulation was different from the LGM case. The regional climate of the Labrador Sea area and surroundings (including Greenland) 
could become more sensitive to meltwater perturbations. Investigating this sensitivity is beyond the scope of the paper and is the subject of an ongoing study.

\subsection{Perspectives}

Knowing that deep convection perturbation through a freshwater flux in the Labrador, the Nordic Seas and the North Atlantic may trigger transitions from milder to colder glacial conditions, freshwater hosing experiments have long conquered the palaeoclimate modelling community. However, many, if not all experiments investigating the nature of DO events have been setup with very crude forcings, namely present-day, pre-industrial or LGM. Moreover, due to computational costs, only simple models have been used so far in transient experiments of glacial abrupt climate change (Ganopolski, 2003). We have shown that in a fully threedimensional model of intermediate complexity, the base climate varies greatly with different forcings and boundary conditions. In a test to estimate atmospheric $\mathrm{CO}_{2}$ concentrations that allow simulating climate shifts resembling the DO events, Wang and Mysak (2006) found that they only occurred under MIS 3 values. By applying realistic MIS 3 forcings, we discovered relatively low climate sensitivity to GHG forcing, but a high sensitivity to insolation forcing. The mechanism behind the ice sheet melting may be reinterpreted as warmer summers during MIS 3 could have provided a baseline melt water flow to the North Atlantic. In this case, freshwater forcing into the North Atlantic would not only form a theoretical exercise, but would be physically consistent.

A first attempt at modelling glacial abrupt climate events in a physically consistent way was undertaken by Ganopolski (2003), Claussen et al. (2005) and Jin et al. (2007) in an earth system model of intermediate complexity incorporating a two-dimensional ocean model. By applying transient MIS 3 forcings, they obtain a Greenland temperature evolution not unlike the observed changes associated with DO events. In their model, the simulated DO events are a robust phenomenon under a broad range of NH ice sheet volume. However, their exercise could be improved by applying all known boundary condition changes. Furthermore, employing threedimensional Ocean General Circulation Models would provide insight on longitudinally asymmetric changes in overturning, e.g. the presence or absence of Labrador Sea convection.

No great source of freshwater to the North Atlantic would have been present during stadials without HEs, however (e.g. Bond et al., 1993; van Kreveld et al., 2000). This is in contrast with certain sites in the Nordic Seas (Rasmussen et al., 1996; Rasmussen and Thomsen, 2004) where planktonic and benthic $\delta^{18} \mathrm{O}$ levels in combination with IRD layers indicate a freshwater source during all cooling phases from interstadials to stadials during MIS 3. Using such information, we may setup more realistic freshwater hosing experiments, for instance by selecting key regions for the freshwater input. Recently, it has been shown that freshwater forcing in different regions causes different response of the oceanic circulation (Roche and Renssen, 2008). We thus propose to design physically consistent DO experiments, by carefully setting up the model with realistic forcings.

\section{Conclusions}

In our MIS 3 climate simulations with the three-dimensional earth system model LOVECLIM, we find a warmer base climate than that of LGM simulated with the same model. Boundary conditions were different during MIS 3 than at LGM, notably insolation, ice sheet configuration, atmospheric greenhouse gases and dust concentrations, all leading to a positive forcing. Our main findings are:

- With smaller Northern Hemisphere ice sheets, higher greenhouse gases and lower dust concentration, MIS 3 mean annual temperatures are higher than LGM (globally $+1.7^{\circ} \mathrm{C}$ for MIS3-sta and $+2.0^{\circ} \mathrm{C}$ for MIS3-int).

- Orbital insolation forcing leads to enhanced Northern Hemisphere seasonality, with mainly warmer summers due to an increase of summer insolation, whereas winter insolation does not change substantially. Northern hemisphere mean July temperature anomalies compared to LGM are $+3.5^{\circ} \mathrm{C}$ for MIS3-sta $\left(+5.7^{\circ} \mathrm{C}\right.$ between $30^{\circ} \mathrm{N}$ and $90^{\circ} \mathrm{N}$ ) and $+3.8^{\circ} \mathrm{C}$ for MIS3-int. The sensitivity of the MIS 3 climate to insolation changes is relatively high (up to $1^{\circ} \mathrm{C}$ per $4 \mathrm{~W} \mathrm{~m}^{-2}$ ). June insolation is $39 \mathrm{~W} \mathrm{~m}^{-2}$ higher in MIS3-sta than in LGM, which explains about half $\left(2.5^{\circ} \mathrm{C}\right.$ between $30^{\circ} \mathrm{N}$ and $\left.90^{\circ} \mathrm{N}\right)$ of the July temperature differences.

- With only greenhouse gases and dust concentration forcing different between a colder (MIS3-sta) and a warmer (MIS3-int) experiment, large temperature differences found in data between cold stadials and mild interstadials over Europe and the North Atlantic region cannot be explained. The different forcings between the two states result in a global temperature difference of $0.3^{\circ} \mathrm{C}$ in annual means, as well as in January and July (and less than $1^{\circ} \mathrm{C}$ over Europe and the North Atlantic region). These small differences point to a low sensitivity of the MIS 3 climate to the reconstructed greenhouse gases and dust concentration changes during that period. In our simulations, the MIS3-sta climate is not cold enough to represent stadial conditions in Europe, whereas MIS3-int better mimics interstadial climate.

- The overall strength of the Atlantic meridional overturning circulation does not differ substantially between LGM and MIS 3. However, in MIS 3 convection sites 
shift more northward in the Atlantic with deep convection found in the Labrador Sea and enhanced convection taking place in the Nordic Seas. Both areas are not covered by perennial sea-ice in our MIS 3 simulations. With Labrador Sea deep convection in our MIS 3 simulations but not in the LGM experiments, the configuration of the Atlantic Thermohaline Circulation is different between MIS 3 and LGM. Since the Labrador Sea is close to the Laurentide and Greenland ice sheets, it can be expected that deep convection here is susceptible to variations in freshwater input. This could have important implications for the climate over the Northwest Atlantic region and downwind areas (such as Southern Greenland). Hence, an LGM state should not be used to simulate DO events.

- If we add $0.3 \mathrm{~Sv}$ of freshwater to the North Atlantic Ocean in our stadial simulation, we shut down the Atlantic thermohaline circulation, leading to a much colder climate over Europe and the North Atlantic region. The annual mean temperatures in these two regions are $7.4^{\circ} \mathrm{C}$, respectively $6.9^{\circ} \mathrm{C}$ colder than in MIS3-sta. The simulated cooling leads to a better temperature match with permafrost reconstructions over Europe regarding stadials than in our MIS3-sta simulation. This simulation compares to previous glacial simulations with shutdown thermohaline circulation, with freshwater forcing explaining most of the temperature difference between modelled stadials and interstadials.

Our findings contribute to understanding the mechanisms behind Dansgaard-Oeschger events. In our model, the cold state with freshwater forcing is more consistent with observed stadial climate than the one without. In this view, stadials would be unstable, colder intervals, while interstadial climate would be closer to our modelled MIS 3 equilibrium state. This MIS 3 equilibrium state is generally warmer than the LGM. We need to design physically consistent climate modelling experiments based on boundary conditions that are realistically representing the period of interest. We confirm once more that insolation differences in glacial periods are important, which we have shown for MIS 3 as compared to LGM.

Acknowledgements. This work is a contribution to the RESOLuTION-project (ESF EUROCORES on EuroCLIMATE program). C. J. V. M. was sponsored by the Netherlands Organisation for Scientific Research (NWO), under contract number 855.01.085. D. M. R. was sponsored by the NWO under contract number 854.00.024. We wish to thank referee A. Ganopolski and an anonymous referee for their thorough review, the manuscript greatly benefited from their suggestions.

Edited by: D.-D. Rousseau

\section{References}

Alfano, M. J., Barron, E. J., Pollard, D., Huntley, B., and Allen, J.: Comparison of climate model results with European vegetation and permafrost during Oxygen Isotope Stage Three, Quaternary Res., 59, 97-107, 2003.

Barron, E. J. and Pollard, D.: High-resolution climate simulations of oxygen isotope stage 3 in Europe, Quaternary Res., 58, 296309, 2002.

Berger, A. L.: Long-term variations of daily insolation and Quaternary climatic changes, J. Atmos. Sci., 35, 2363-2367, 1978.

Berger, A. and Loutre, M. F.: Insolation values for the climate of the last 10 million years, Quaternary Sci. Rev., 10, 297-317, 1991.

Bond, G., Broecker, W., Johnsen, S., McManus, J., Labeyrie, L., Jouzel, J., and Bonani, G.: Correlations between climate records from North Atlantic sediments and Greenland ice, Nature, 365, 143-147, 1993.

Broecker, W. S., Peteet, D. M., and Rind, D.: Does the oceanatmosphere system have more than one stable mode of operation? Nature, 315, 21-26, doi:10.1038/315021a0, 1985.

Broecker, W. S.: Massive iceberg discharges as triggers for global climate change, Nature, 372, 421-424, 1994.

Broecker, W. S., Peng, T.-H., Jouzel, J., and Russell, G.: The magnitude of global fresh-water transports of importance to ocean circulation, Clim. Dynam., 4, 73-79, 1990.

Brovkin, V., Ganopolski, A., and Svirezhev, Y.: A continuous climate-vegetation classification for use in climate-biosphere studies, Ecol. Model., 101, 251-261, 1997.

Chappell, J.: Sea level changes forced ice breakouts in the Last Glacial cycle: new results from coral terraces, Quaternary Sci. Rev., 21, 1229-1240, 2002.

Claquin, T., Roelandt, C., Kohfeld, K., Harrison, S., Tegen, I., Prentice, I., Balkanski, Y., Bergametti, G., Hansson, M., Mahowald, N., Rodhe, H., and Schulz, M.: Radiative forcing of climate by ice-age atmospheric dust, Clim. Dynam., 20, 193-202, 2003.

Clark, P. U., Hostetler, S. V., Pisias, N. G., Schmittner, A., and Meissner, K. J.: Mechanisms for an 7-kyr Climate and SeaLevel Oscillation During Marine Isotope Stage 3, in: Ocean Circulation: Mechanisms and impacts-Past and future changes of meridional overturning, edited by: Schmittner, A., Chiang, J. C. H., and Hemming, S. R., American Geophysical Union, Washington, DC, USA, 209-246, 2007.

Claussen, M., Ganopolski, A., Brovkin, V., Gerstengarbe, F.-W., and, Werner, P.: Simulated global-scale response of the climate system to Dansgaard/Oeschger and Heinrich events, Clim. Dynam., 21, 361-370, 2003.

Coope, G. R., Gibbard, P. L., Hall, A. R., Preece, R. C., Robinson, J. E., and Sutcliffe, A. J.: Climatic and environmental reconstructions based on fossil assemblages from Middle Devensian (Weichselian) deposits of the river Thames at South Kensington, Central London, UK, Quaternary Sci. Rev., 16, 1163-1195, 1997.

Dansgaard, W., Johnsen, S. J., Clausen, H. B., Dahl-Jensen, D., Gundestrup, N. S., Hammer, C. U., Hvidberg, C. S., Steffensen, J. P., Sveinbjörnsdottir, A. E., Jouzel, J., and Bond, G.: Evidence for general instability of past climate from a 250-kyr ice-core record, Nature, 364, 218-220, 1993.

Dokken, T. and Jansen, E.: Rapid changes in the mechanism of ocean convection during the last glacial period, Nature, 401, 458-461, 1999. 
Driesschaert, E.: Climate change over the next millennia using LOVECLIM, a new Earth system model including the polar ice sheets, Ph.D. thesis, Université Catholique de Louvain, Louvain-la-Neuve, Belgium, http://www.astr.ucl.ac.be/ users/driess/thesis_web.pdf, 2005.

Ehlers, J. and Gibbard, P. L.: Quaternary Glaciations - Extent and Chronology: Part II: North America, Elsevier, Amsterdam, 440 pp., 2004.

Engels, S., Bohncke, S. J. P., Bos, J. A. A., Brooks, S. J., Heiri, O., and Helmens, K. F.: Chironomid-based palaeotemperature estimates for northeast Finland during Oxygen Isotope Stage 3, J. Paleolimnology, 40(1), 49-61, doi:10.1007/s10933-007-9133y, 2007.

EPICA-community-Members: One-to-one coupling of glacial climate variability in Greenland and Antarctica, Nature, 444, 195198, 2006.

Flückiger, J., Blunier, T., Stauffer, B., Chappellaz, J., Spahni, R., Kawamura, K., Schwander, J., Stocker, T. F., and DahlJensen, D.: $\mathrm{N}_{2} \mathrm{O}$ and $\mathrm{CH}_{4}$ variations during the last glacial epoch: Insight into global processes, Global Biogeochem. Сy., 18, GB1020, doi:10.1029/2003GB002122, 2004.

Flückiger, J., Knutti, R., White, J. W. C., and Renssen, H.: Modeled seasonality of glacial abrupt climate events, Clim. Dynam., 31, 633-645, doi:10.1007/s00382-008-0373-y, 2008.

Ganopolski, A.: Glacial Integrative Modelling, Philos. T. Roy. Soc. A. 361, 1871-1884, 2003.

Ganopolski, A. and Rahmstorf, S.: Rapid changes of glacial climate simulated in a coupled model, Nature, 409, 153-158, 2001.

Ganopolski, A. and Rahmstorf, S.: Abrupt Glacial Climate Changes due to Stochastic Resonance, Phys. Rev. Lett., 88(3), 038501, doi:10.1103/PhysRevLett.88.038501, 2002.

Goosse, H. and Fichefet, T.: Importance of ice-ocean interactions for the global ocean circulation: A model study, J. Geophys. Res., 104(C10), 23337-23355, doi:10.1029/1999JC900215, 1999.

Heinrich, H.: Origin and consequences of cyclic ice rafting in the Northeast Atlantic Ocean during the past 130,000 years, Quaternary Res., 29, 142-152, 1988.

Helmens, K. F., Bos, J. A. A., Engels, S., Van Meerbeeck, C. J., Bohncke, S. J. P., Renssen, H., Heiri, O., Brooks, S. J., Seppä, H., Birks, H. J. B., and Wohlfarth, B.: Present-day summer temperatures in northern Scandinavia during the Last Glaciation, Geology, 35(11), 987-990, doi:10.1130/G23995A.1, 2007.

Hemming, S. R.: Heinrich events: Massive late Pleistocene detritus layers of the North Atlantic and their global climate imprint, Rev. Geophys., 42, RG1005, doi:10.1029/2003RG000128, 2004.

Huber, C., Leuenberger, M., Spahni, R., Flückiger, J., Schwander, J., Stocker, T. F., Johnsen, S. J., Landais, A., and Jouzel, J.: Isotope calibrated Greenland temperature record over Marine Isotope Stage 3 and its relation to $\mathrm{CH}_{4}$, Earth Planet. Sc. Lett., 243, 504-519, 2006.

Huijzer, B. and Vandenberghe, J.: Climatic reconstruction of the Weichselian Pleniglacial in northwestern and central Europe, J. Quaternary Sci., 13(5), 391-417, 1998.

Indermühle, A., Monnin, E., Stauffer, B., Stocker, T. F., and Wahlen, M.: Atmospheric CO2 concentration from 60 to $20 \mathrm{kyr}$ BP from the Taylor Dome ice core, Antarctica, Geophys. Res. Lett., 27(5), 735-738, 2000.

Jin, L., Chen, F., Ganopolski, A., and Claussen, M., Response of
East Asian climate to Dansgaard/Oeschger and Heinrich events in a coupled model of intermediate complexity, J. Geophys. Res., 112, D06117, doi:10.1029/2006JD007316, 2007.

Knutti, R., Flückiger, J., Stocker, T. F. and Timmermann, A.: Strong hemispheric coupling of glacial climate through freshwater discharge and ocean circulation, Nature, 430, 851-856, 2004.

Lambeck, K. and Chappell, J.: Sea Level Change through the Last Glacial Cycle, Science, 292, 679-686, 2001.

Lee, S. Y. and Poulsen, C. J.: Amplification of obliquity forcing through mean annual and seasonal atmospheric feedbacks, Climate of the Past, 4, 205-213, 2008.

MacAyeal, D. R.: Binge/purge oscillations of the Laurentide ice sheet as a cause of the North Atlantic's Heinrich events, Paleoceanography, 8(6), 775-784, doi:10.1029/93PA02200, 1993.

Mahowald, N., Kohfeld, K., Hansson, M., Balkanski, Y., Harrison, S. P., Prentice, I. C., Schulz, M., and Rodhe, H.: Dust sources and deposition during the last glacial maximum and current climate: A comparison of model results with paleodata from ice cores and marine sediments, J. Geophys. Res., 104(D13), 15895-15916, 1999.

Mahowald, N. M., Muhs, D. R., Levis, S., Rasch, P. J., Yoshioka, M., Zender, C. S., and Luo, C.: Change in atmospheric mineral aerosols in response to climate: Last glacial period, preindustrial, modern, and doubled carbon dioxide climates, J. Geoph. Res., 111, D10202, doi:10.1029/2005JD006653, 2006.

NorthGRIP-Members: High-resolution record of Northern Hemisphere climate extending into the last interglacial period, Nature, 431, 147-151, 2004.

Opsteegh, J., Haarsma, R., Selten, F., and Kattenberg, A.: ECBILT: A dynamic alternative to mixed boundary conditions in ocean models, Tellus, 50, 348-367, 1998.

Peltier, W.: Global Glacial Isostasy and the Surface of the Ice-Age Earth: The ICE-5G (VM2) Model and GRACE, Annu. Rev. Earth Pl. Sc., 32, 111-149, doi:10.1146/annurev.earth.32.082503.144359, 2004.

Pollard, D. and Barron, E. J.: Causes of model-data discrepancies in European climate during Oxygen Isotope Stage 3 with insights from the last glacial maximum, Quaternary Res., 59, 108-113, 2003.

Prange, M., Romanova, V., and Lohmann, G.: The glacial thermohaline circulation: stable of unstable?, Geophys. Res. Lett., 29, 2028-2031, 2002.

Rahmstorf, S.: On the freshwater forcing and transport of the Atlantic thermohaline circulation, Clim. Dynam., 12, 799-811, 1996.

Rasmussen, T. L., Thomsen, E., Labeyrie, L., and van Weering, T. C. E.: Circulation changes in the Faeroe-Shetland Channel correlating with cold events during the last glacial period (58$10 \mathrm{ka})$, Geology, 24(10), 937-940, 1996.

Rasmussen, T. L. and Thomsen, E.: The role of the North Atlantic Drift in the millennial timescale glacial climate fluctuations, Palaeogeogr. Palaeocl. 210, 101-116, 2004.

Rial, J. A. and Yang, M.: Is the frequency of abrupt climate change modulated by the orbital insolation? in: Ocean Circulation: Mechanisms and impacts - Past and future changes of meridional overturning, edited by: Schmittner, A., Chiang, J. C. H., and Hemming, S. R., American Geophysical Union, Washington, DC, USA, 167-174, 2007.

Roche, D. M., Dokken, T. M., Goosse, H., Renssen, H., and Weber, 
S. L.: Climate of the Last Glacial Maximum: sensitivity studies and model-data comparison with the LOVECLIM coupled model, Clim. Past, 3, 205-224, 2007,

http://www.clim-past.net/3/205/2007/.

Roche, D. M. and Renssen, H.: Triggering abrupt climate change by freshwater perturbations of the LGM surface ocean: a systematic study of the sensitivity to different release locations, Geophys. Res. A., 10, EGU2008-A-03805, 2008.

Sakai, K. and Peltier, W.R.: Dansgaard-Oeschger oscillations in a coupled atmosphere-ocean climate model, J. Climate, 10, 949970, 1997.

Schulz, M.: On the 1470-year pacing of Dansgaard-Oeschger warm events, Paleoceanography, 17(2), 4, doi:10.1029/2000PA000571, 2002.

Severinghaus, J. P., Sowers, T., Brook, E. J., Alley, R. B., and Bender, M. L.: Timing of abrupt climate change at the end of the Younger Dryas interval from thermally fractionated gases in polar ice, Nature, 391, 141-146, 1998.

Stocker T. F. and Broecker, W. S.: Observation and modeling of North Atlantic deep water formation and its variability: Introduction, J. Geophys. Res., 99, 12317, 1994.

Stouffer, R. J., Yin, J., Gregory, J. M., Dixon, K. W., Spelman, M. J., Hurlin, W., Flato, G. M., Weaver, A. J., Eby, M., Hasumi, H., Hu, A., Jungclaus, J. H., Kamenkovitch, L. V., Levermann, A., Montoya, M., Murakami, S., Nawrath, S., Oka, A., Peltier, W. R., Robitaille, D. Y., Sokolov, A., Vettoretti, G., and Weber, S. L.: Investigating the Causes of the Response of the Thermohaline Circulation to Past and Future Climate Changes, J. Climate, 19, 1365-1387, 2006.

Svendsen, J., Alexanderson, H., Astakhov, V., Demidov, I., Dowdeswell, J., Funder, S., Gataullin, V., Henriksen, M., Hjort, C., Houmark-Nielsen, M., Ingólfsson, H. H. O., Jakobsson, M., Kjaer, K., Larsen, E., Lokrantz, H., Lunkka, J., Lysa, A., Mangerud, J., Matiouchkov, A., Murray, A., Möller, P., Niessen, F., Nikolskaya, O., Polyak, L., Saarnisto, M., Siegert, C., Siegert, M., Spielhagen, R., and Stein, R.: Late Quaternary ice sheet history of northern Eurasia, Quaternary Sci. Rev., 23, 1229-1271, doi:10.1016/j.quascirev.2003.12.008, 2004.
Tartinville, B., Campin, J., Fichefet, T., and Goosse, H.: Realistic representation of the surface freshwater flux in an ice-ocean general circulation model, Ocean Model., 3, 95-108, 2001.

van Andel, T. H.: Reconstructing climate and landscape of the last mid-pleniglacial in Europe - the stage 3 project, Quaternary Res., 57, 2-8, 2002.

Vandenberghe, J.: Geomorphology and climate of the cool oxygen isotope stage 3 in comparison with the cold stages 2 and 4 in The Netherlands, Z. Geomorph. N. F., Suppl.-Bd., 86, 65-75, 1992.

van Huissteden, K., Vandenberghe, J., and Pollard, D.: Palaeotemperature reconstructions of the European permafrost wone during marine oxygen isotope Stage 3 compared with climate model results, J. Quaternary Sci., 18, 453-464, 2003.

van Kreveld, S., Sarnthein, M., Erlenkeuser, H., Grootes, P., Jung, S., Nadeau, M.J., Pflaumann, U., and Völker, A.: Potential links between surging ice sheets, circulation changes, and the Dansgaard-Oeschger cycles in the Irminger Sea, 60-18 kyr, Paleoceanography, 14(4), 425-442, 2000.

Voelker, A. H. L.: Global distribution of centennial-scale records for Marine Isotope Stage (MIS) 3: a database, Quaternary Sci. Rev., 21(10), 1185-1212, doi:10.1016/S0277-3791(01)00139-1, 2002.

Wang, Z. and Mysak, L. A.: Glacial abrupt climate changes and Dansgaard-Oeschger oscillations in a coupled climate model, Paleoceanography, 21, PA2001, doi:10.1029/2005PA001238, 2006.

Weber, S. L., Drijfhout, S. S., Abe-Ouchi, A., Crucifix, M., Eby, M., Ganopolski, A., Murakami, S., Otto-Bliesner, B., and Peltier, W. R.: The modern and glacial overturning circulation in the Atlantic ocean in PMIP coupled model simulations, Clim. Past, 3, 51-64, 2007, http://www.clim-past.net/3/51/2007/. 